\title{
Meiotic Nuclear Architecture in Distinct Mole Vole Hybrids with Robertsonian Translocations: Chromosome Chains, Stretched Centromeres, and Distorted Recombination
}

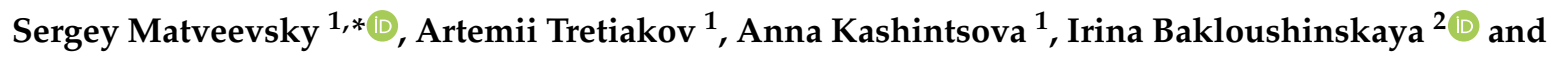 \\ Oxana Kolomiets ${ }^{1}$ \\ 1 Laboratory of Cytogenetics, Vavilov Institute of General Genetics, Russian Academy of Sciences, \\ 119991 Moscow, Russia; temanch@gmail.com (A.T.); koly4kina2009@mail.ru (A.K.); \\ olkolomiets@mail.ru (O.K.) \\ 2 Laboratory of Genome Evolution and Mechanisms of Speciation, Koltzov Institute of Developmental \\ Biology, Russian Academy of Sciences, 119334 Moscow, Russia; irina.bakl@gmail.com \\ * Correspondence: sergey8585@mail.ru
}

Received: 27 September 2020; Accepted: 13 October 2020; Published: 15 October 2020

\begin{abstract}
Genome functioning in hybrids faces inconsistency. This mismatch is manifested clearly in meiosis during chromosome synapsis and recombination. Species with chromosomal variability can be a model for exploring genomic battles with high visibility due to the use of advanced immunocytochemical methods. We studied synaptonemal complexes (SC) and prophase I processes in 44-chromosome intraspecific (Ellobius tancrei $\times$ E. tancrei) and interspecific (Ellobius talpinus $\times E$. tancrei) hybrid mole voles heterozygous for 10 Robertsonian translocations. The same pachytene failures were found for both types of hybrids. In the intraspecific hybrid, the chains were visible in the pachytene stage, then 10 closed SC trivalents formed in the late pachytene and diplotene stage. In the interspecific hybrid, as a rule, SC trivalents composed the SC chains and rarely could form closed configurations. Metacentrics involved with SC trivalents had stretched centromeres in interspecific hybrids. Linkage between neighboring SC trivalents was maintained by stretched centromeric regions of acrocentrics. This centromeric plasticity in structure and dynamics of SC trivalents was found for the first time. We assume that stretched centromeres were a marker of altered nuclear architecture in heterozygotes due to differences in the ancestral chromosomal territories of the parental species. Restructuring of the intranuclear organization and meiotic disturbances can contribute to the sterility of interspecific hybrids, and lead to the reproductive isolation of studied species.
\end{abstract}

Keywords: nuclear architecture; stretched centromere; synaptonemal complex; chromatin; meiosis; hybrid sterility; Ellobius; Robertsonian translocation

\section{Introduction}

Genome integrity is crucial for a species; its specificity is supported by reproductive isolation. Hybrid sterility may develop between species or genetically differentiated populations, as a primary or secondary feature of reproductive isolation [1-5]. Two genetic materials in a heterozygous admixed genome interact in various compositions [6] and these hybrid states are often referred to as "genomic conflict" [7,8], "genomic shock" [9,10], "genomic stress" [9,11], or "nucleus at war" [12].

Hybrid incompatibility $[1,13,14]$ is expressed either by visible or cryptic changes in the phenotype [15-17] or disturbances in chromosome sets and gene expression and alterations in the gene networks $[16,18,19]$. Epistatic interactions between chromosomal regions (heterochromatin blocks, 
centromeres, and telomeres), satellite DNA, small RNA, and epigenetic chromatin modifications [20] are essential for the emergence of Dobzhansky-Muller incompatibility. Hybrid and heterozygous animals are excellent models for studying the effect of chromosomal rearrangements on the development of the organism, cellular function, intracellular structures, germ cell formation-including the most important stage, meiosis-and, in general, chromosomal evolution. Chromosome differences in hybrid meiocytes can manifest as various irregularities in chromosome synapsis, recombination, chromatin landscape, and transcriptional inactivation [21-24].

Chromosome heterozygosity can be studied either in laboratory hybrids [25-30] or in natural hybrids, for example, from hybrid zones [31-33]. Experimental hybridization allows researchers to obtain offspring from parental forms with known karyotypic data, which facilitates a more accurate assessment of the effect of structural hybridity on the processes of cell division, morphology, and fertility $[34,35]$.

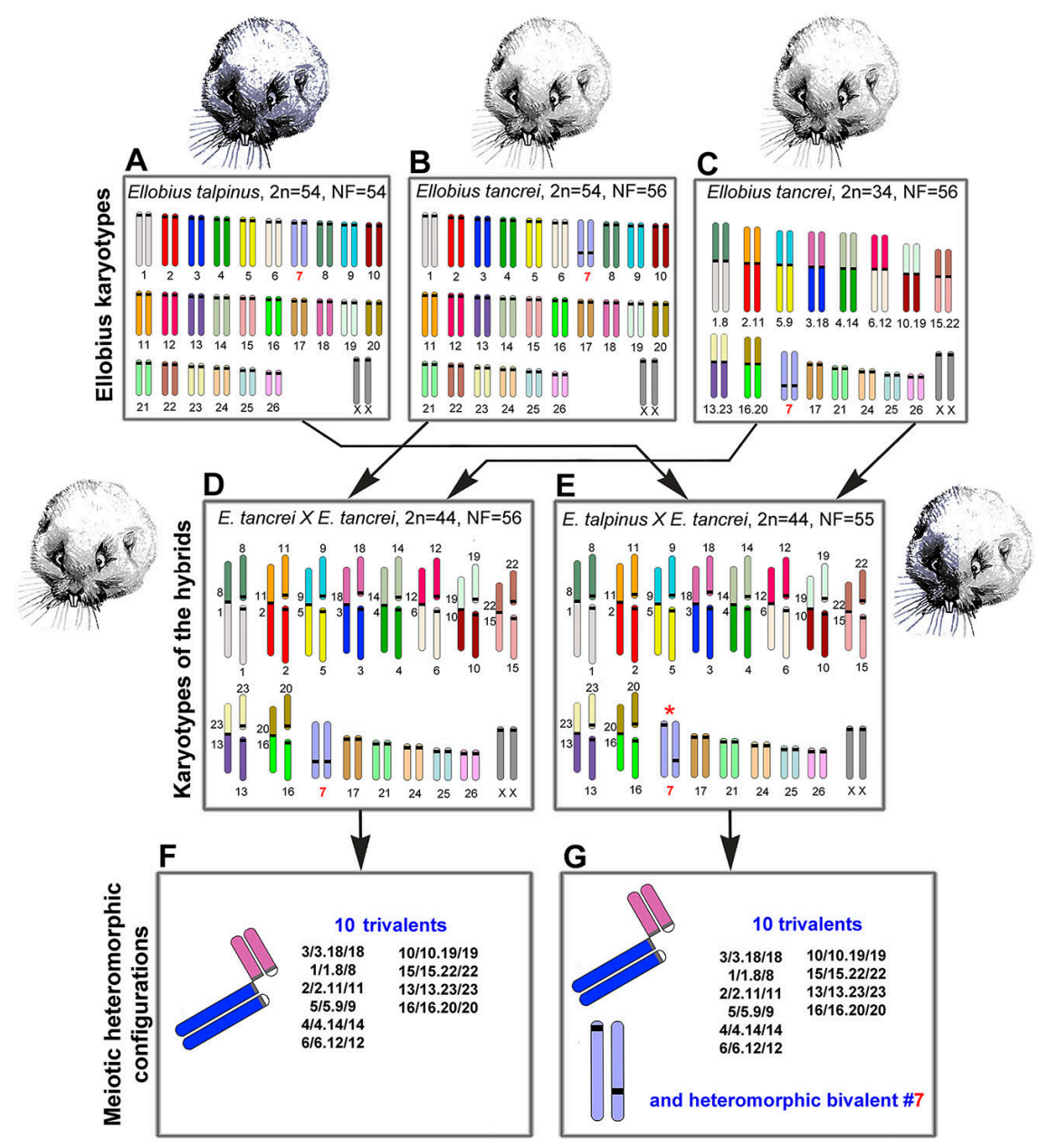

Figure 1. Scheme of the experimental hybridization of Ellobius species and hybrids. (A-C) Karyotypes for E talpinus, $2 n=54, \mathrm{NF}=54(\mathrm{~A})$; E. tancrei, $2 n=54, \mathrm{NF}=56$ (B); and E. tancrei, $2 n=34, \mathrm{NF}=56$ (C). $($ D,E) F1 hybrid karyotypes for E. tancrei $\times$ E. tancrei, $2 n=44, \mathrm{NF}=56$ (D) and E. talpinus $\times$ E. tancrei, $2 n$ $=44, \mathrm{NF}=55(\mathrm{E}) .(\mathrm{F}, \mathrm{G})$ Chromosome heteromorphic configurations in meiotic prophase I of F1 hybrids: 10 trivalents $(\mathbf{F})$, and 10 trivalents and the heteromorphic chromosome \#7 (G).

Mole voles are gratifying sources for experimental hybridization. One of the three cryptic species has a stable karyotype, namely Ellobius talpinus $(2 n=54, \mathrm{NF}=54)$, and no natural hybrids are known [36]. Two other species have Robertsonian $(\mathrm{Rb})$ chromosome variability: Ellobius tancrei $(2 n=$ $54-30, \mathrm{NF}=56)$ and Ellobius alaicus $(2 n=52-48, \mathrm{NF}=56)$ [37-41]. These species demonstrate intraand interspecific hybridization [41,42]. The 54-chromosome karyotypes of E. talpinus and E. tancrei are 
identical and differ only in chromosome \#7 due to centromere repositioning [43]. Ten pairs of bi-armed $(\mathrm{Rb})$ chromosomes are a feature of the 34-chromosome karyotype of E. tancrei [42] (Figure 1). Karyotypic variability allows researchers to simulate different natural chromosomal combinations in experimental hybrids [44-52]. The first description of chromosome chains was made for an intraspecific E. tancrei hybrid heterozygous for $10 \mathrm{Rb}$ translocations $[45,53]$. It would be extremely interesting to compare the heterozygotes with the same diploid numbers obtained from crossing E. tancrei chromosomal forms between themselves and between two species, E. talpinus and E. tancrei.

In this study, we first compared chromosome synapsis and recombination in intra- and interspecific hybrids with the same chromosome number and with numerous translocations. We analyzed 44-chromosome F1 hybrids, intraspecific E. tancrei $\times$ E. tancrei, and interspecific E. talpinus $\times$ E. tancrei, heterozygous for 10 identical $\mathrm{Rb}$ translocations (Figure 1, compare D and E). Each of the hybrids is expected to form 10 identical SC trivalents. A comparative analysis of chromosome synapsis, recombination, and meiotic silencing in the fertile and sterile hybrids allowed us to assess the effect of chromosome rearrangements on these processes, as well as to draw conclusions about the degree of species divergence.

\section{Results}

\subsection{Experimental Hybridization}

We studied parental mole vole species-E. talpinus $(2 n=54, \mathrm{NF}=54)$, E. tancrei $(2 n=54, \mathrm{NF}=56)$, and another form of E. tancrei $(2 n=34, \mathrm{NF}=56)$-and F1 hybrids-intraspecific E. tancrei $\times$ E. tancrei $(2 n=44, \mathrm{NF}=56)$ and interspecific E. talpinus $\times$ E. tancrei $(2 n=44, \mathrm{NF}=55)($ Figure 1$)$.

The karyotypes of interspecific and intraspecific hybrids differ little from each other. They include 5 pairs of acrocentrics, 10 metacentrics and 20 acrocentrics, which are homologous to the arms of metacentrics, pair \#7 and a pair of isomorphic sex (XX) chromosomes. Two types of hybrids differ only by the chromosome \#7 pair. In the interspecific hybrid, this pair is heteromorphic (Figure 1), while in the intraspecific hybrid, it is represented by a pair of homologous submetacentrics. In total, we detected 10 SC trivalents, 6 SC bivalents, including a heteromorphic SC bivalent in the interspecific hybrid, and a sex XX bivalent in meiotic prophase I in spermatocyte spreads and squashes of both hybrids (Figure 1).

The gonadosomatic index (GSI) can be used as an indicator of the state of the reproductive system. It is calculated as the ratio of the weight of the testes to the weight of the body [54]. This parameter is species specific; it varies depending on age, stage of development, sex, and breeding season [55] and may reflect the rates of sperm production as well as sperm function [56]. Comparison of the parameter in closely related forms, species, and hybrids can be informative. Hence, we calculated the GSIs in adult mole voles, parental species, and hybrids. GSI (mean (M) \pm standard deviation (SD)) in the interspecific hybrid $(0.11 \pm 0.04, n=3)$ was approximately half of the E. talpinus GSI $(0.20 \pm 0.02$, $n=3)$ and approximately one third of the E. tancrei $(2 n=34)$ GSI $(0.31 \pm 0.10, n=3)$. Species and hybrids significantly differ from each other in this parameter $(p<0.05)$. This indicator suggests that interspecific hybrids have reproductive dysfunction. Unfortunately, we do not have data on GSI of intraspecific hybrids.

There were numerous spermatocytes and mature spermatids in the testicular cell suspension of the parental species and the intraspecific hybrids (Figure S1A-D). In the interspecific hybrids, the number of spermatocytes was significantly lower, and mature spermatids and spermatozoa were not detected at all, which was confirmed by histological examination of testicular tissue sections (Figure S1B-D). Testicles of the interspecific hybrids were significantly smaller than in 34-chromosome parental forms (Figure S1E). Testis weights (and most likely testis volumes) $<55 \%$ of normal values indicate sterility [57]. None of the 93 interspecific F1 E. talpinus $\times$ E. tancrei hybrids produced offspring (shown graphically in Figure S1F, compare all species and hybrids). The fertility data of mole voles in this work are in good agreement with the previous data [47]. Moreover, for the intraspecific hybrids, there 
was an increased time interval from the moment of coupling to the first litter and an increased period between births compared with the parental forms [47]. Thus, the intraspecific hybrid had slightly reduced fertility, and the interspecific hybrid was sterile.

\subsection{Synaptic Behavior of Chromosomes}

We first described the chromosome behavior in pachytene spermatocytes of parental forms. In $E$. talpinus, there were 26 acrocentric bivalents and a sex (XX) bivalent, covered by a $\gamma \mathrm{H} 2 \mathrm{AFX}$ cloud, that moved to the periphery of the nucleus (Figure 2A and Figure S2A-C). In 54-chromosome E. tancrei, there were 25 acrocentric SC bivalents and 1 submetacentric SC bivalent, and an XX bivalent, covered by a $\gamma \mathrm{H} 2 \mathrm{AFX}$ cloud, that moved to the periphery of the nucleus (Figure $2 \mathrm{~B}$ and Figure S2D-F). In 34-chromosome E. tancrei, there were 10 metacentric SC bivalents, 1 submetacentric SC bivalent $\# 7$, and 5 acrocentric bivalents, and an XX bivalent, covered by a $\gamma \mathrm{H} 2 \mathrm{AFX}$ cloud, that moved to the nuclear periphery (Figure 2C and Figure S2G-I).
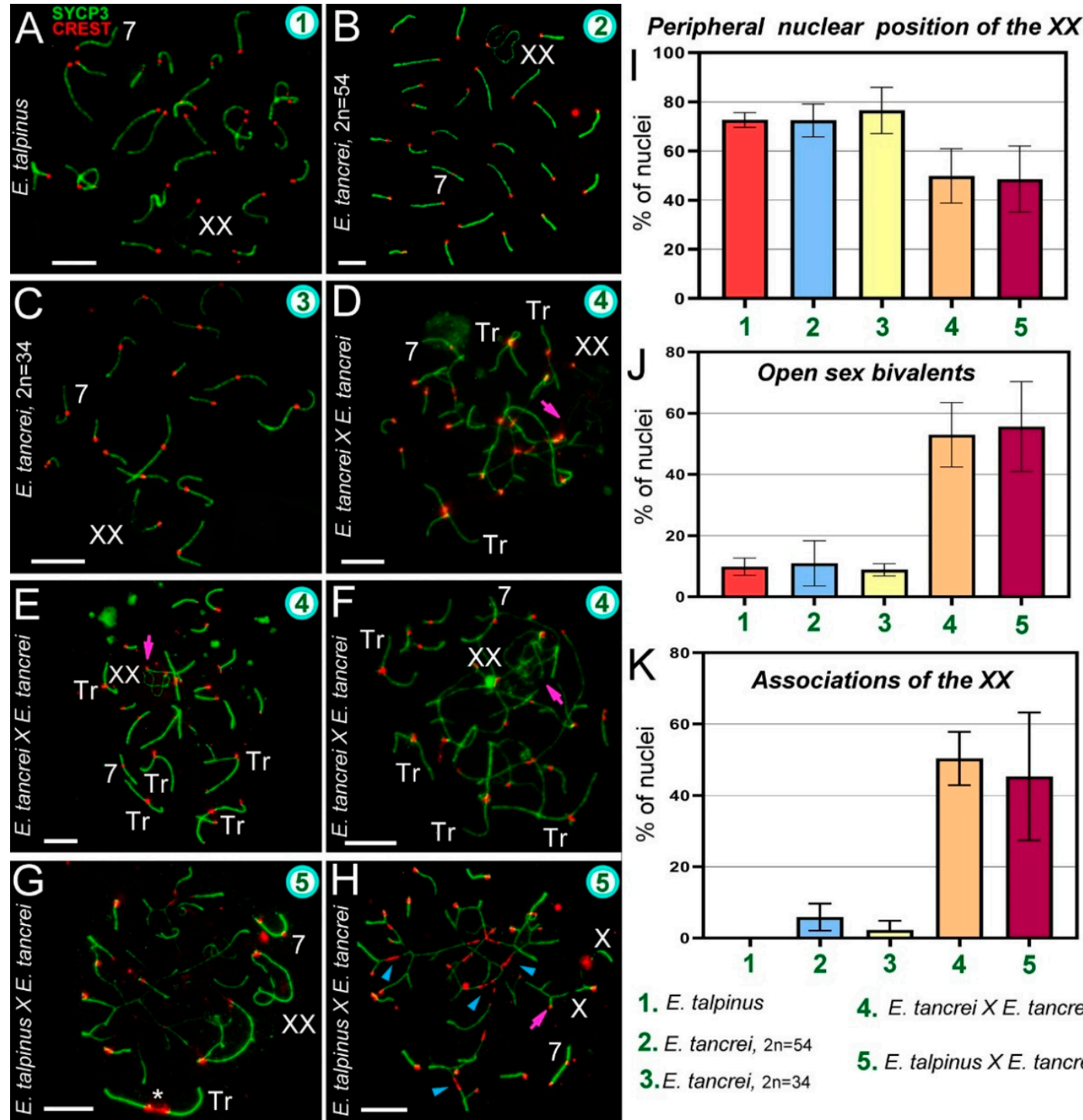
1. E. talpinus
4. E. tancrei X E. tancrei
2. E. tancrei, $2 \mathrm{n}=54$
3.E. tancrei, $2 \mathrm{n}=34$
5. E. talpinus $X E$. tancrei

Figure 2. Chromosome synapsis and irregularities in pachytene spermatocytes of Ellobius species and hybrids. The green numbers in the micrographs and diagrams correspond to parental species and hybrids (see captions under diagram K). Pink arrows show associations of the sex (XX) bivalents 
(D,E,F,H). Chromosome \#7 was clearly identified in all nuclei (A-H). (A) Ellobius talpinus: 26 synaptonemal complexes (SCs) and 1 XX bivalent. (B) E. tancrei $(2 n=54)$ : 26 SCs and 1 XX bivalent. (C) E. tancrei $(2 n=34)$ : 16 SCs and 1 XX bivalent. (D-F) Intraspecific hybrid E. tancrei $\times$ E. tancrei $(2 n=$ 44): no nucleus had the expected chromosome formula (6 SCs, 1 XX bivalent, 10 SC trivalents). There were several SCs, 3-5 free SC trivalents, an XX bivalent, and SC trivalents in chains. $(\mathbf{G}, \mathbf{H})$ Interspecific hybrid E. talpinus $\times$ E. tancrei $(2 n=44)$ : expected chromosome formula: 6 SCs, 1 XX bivalent, 10 SC trivalents. One nucleus contained 3 SCs, 1 XX bivalent, 1 SC trivalent with a stretched centromere (white star), and SC trivalents in a chain (G). The other nucleus had 6 SCs, 1 XX bivalent, and SC trivalents in a chain (no free SC trivalents) (H). Some metacentrics in the SC trivalents had a stretched centromere (blue arrowheads). (I) The number of cells in which the XX bivalent moved to the periphery of the nuclei: hybrids had significantly lower rates compared with the parent species (see Table S1). (J) The number of cells with an open XX bivalent: this parameter was much higher in hybrids than in parents (Table S1 indicates significant differences). This parameter increased from intraspecific hybrids to interspecific hybrids (differences between them were not significant). For examples of open XX bivalent, see D, E, and H. (K) The number of cells with associations of XX with autosomes and trivalents: there were significant differences between parents and hybrids, and this parameter was slightly higher in the intraspecific hybrid $(2 n=44)$ than in the other hybrid (see Table S1). An open sex bivalent associated with trivalents is shown in D, E, and H. Scale bars represent $5 \mu \mathrm{m}$.

In an intraspecific hybrid, there were 10 closed and open SC trivalents, 5 acrocentric bivalents, 1 submetacentric bivalent \#7, and an XX bivalent (Figure 2D-F and Figure S3A-C). The $\gamma H 2$ AFX cloud completely covered the $\mathrm{XX}$ bivalent and asynaptic regions of the open SC trivalent (Figure S2J-L). In the interspecific hybrid, there were 10 closed and open SC trivalents, 5 acrocentric bivalents, 1 heteromorphic chromosome \#7 bivalent, and an XX bivalent (Figure 2G,H and Figure S4A). The $\gamma H 2 A F X$ cloud completely covered the XX bivalent and some asynaptic regions of open SC trivalents (Figure S2M-O).

The XX bivalent, as a rule, had two telomeric synaptic sites and a large central asynaptic area (closed configuration). A chromatin-dense body (ChB) was formed in one of the axial elements of the $X X^{\prime}$ extended area of asynapsis (Figures S3D and S4C) [58,59]. One of the synaptic sites may have been absent when the axis or axes were associated with SC trivalents or bivalents (open configuration of XX bivalent). Sex chromosomes at the zygotene were presented in the Figure S5.

In mammals, sex bivalents are usually moved to the periphery of meiotic nuclei and covered in a cloud of protein inactivators of asynaptic chromatin. In hybrids, the XX bivalent was significantly less likely to move to the nucleus periphery than in the parents. However, the difference between intraand interspecific hybrids was not statistically significant (Figure 2I, Table S1 [2]). The number of open XX bivalents in hybrids was higher than in parents; the difference between parents and hybrids was significant, but not significant within each of the groups (Figure 2E,H,J, Table S1 [3], Figures S3C,E and S4F).

\subsection{Synapsis Defects and Associations of the XX and SC Trivalents in Hybrids}

Chromosome synapsis defects included atypical lengthening of the short arms of acrocentrics of the SC trivalent in both hybrids (Figure 3), as well as atypical lengthening of one of the synaptic regions of the sex bivalent in the intraspecific hybrid (Figure $3 \mathrm{H}$ ). This lengthening occurred due to a slight stretch at the centromeric region. 

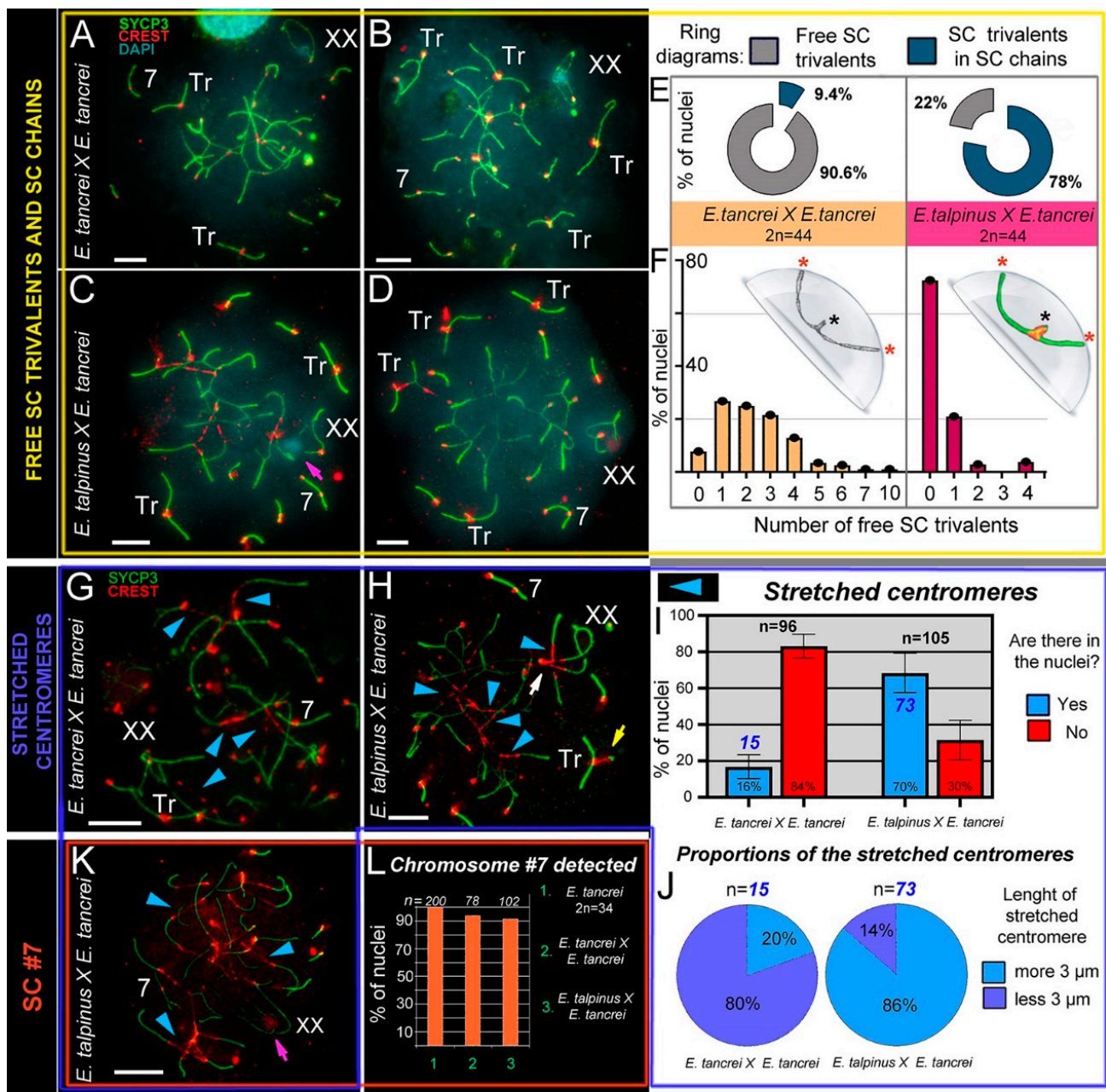

Figure 3. SC trivalents and stretched centromeres in Ellobius hybrids. (A-F) SC trivalents, free and in chains, in 44-chromosome intraspecific $(\mathbf{A}, \mathbf{B})$ and interspecific $(\mathbf{C}, \mathbf{D})$ hybrids. Both hybrids had variations in the number of free closed trivalents (see A-D). Fewer free closed SC trivalents in the nuclei indicated that more open SC trivalents were in the chains. The number of free trivalents in hybrid nuclei was significantly different: $90.6 \%$ in intraspecific $(n=99)$ and $22 \%$ in interspecific $(n=102)$ hybrids (see ring diagrams in E and see Table S1). There were typically 1-4 free SC trivalents identified in most nuclei of intraspecific hybrids (see the light orange columns of the bar chart in F). As a rule, there were no free SC trivalents in most nuclei of interspecific hybrids (see the dark-red columns of the bar chart in F). Free closed SC trivalents simulated in the hemisphere (F): black stars show proximal telomeres of acrocentrics, and red stars show distal telomeres of metacentrics and acrocentrics of SC trivalents. (G-K) Stretched centromeres in SC trivalents (blue arrowheads in $\mathbf{G}, \mathbf{H}, \mathbf{K})$. The prevalence of the stretched centromeres in hybrid nuclei was variable: $16 \%$ (15 nuclei from $n=96)$ in intraspecific and $70 \%$ (73 from $n=105$ ) in interspecific hybrid (see bar chart in I; Table S1 indicates significant differences). The length of the stretched centromeres was different; there were two notable groups: (1) $<3 \mu \mathrm{m}$ and (2) $>3 \mu \mathrm{m}$. Group (1) prevailed in the intraspecific hybrid, while group (2) was more prevalent in the interspecific hybrid (see ring diagrams in J). (L) Prevalence of chromosome \#7 detected in the parent $(2 n=34)$ and hybrids. Chromosome \#7 was clearly identified in all nuclei (see A-D,G,H and $\mathbf{K})$. Parents $(2 n=34)$ always had chromosome \#7 (without chromosome associations). Both types of hybrids had chromosome \#7 in the vast majority of pachytene nuclei (see the columns of the bar chart in L). Pink arrows show associations of the sex (XX) bivalents $(\mathbf{C}, \mathbf{K})$. The white arrow shows atypical lengthening of one of the XX bivalent synaptic sites $(\mathbf{H})$. The yellow arrow shows atypical prolonging of short arms of acrocentrics of the SC trivalent $(\mathbf{H})$. The nucleus in $\mathrm{K}$ is presented in Figure S6A-G). Scale bars represent $5 \mu \mathrm{m}$. 
The interspecific hybrid also exhibited atypically large XX bivalents (Figure 2G) and ring univalents at the pachytene stage (Figure S4I). The intraspecific hybrid showed a triple synapsis in the region of the short arms of the SC trivalent (Figure S3G).

Associations of the XX bivalent with autosomes were rare and only observed in two forms of E. tancrei nuclei: $5.9 \%(2 n=54)$ and $2.25 \%(2 n=34)$. In both F1 hybrids, associations of the sex bivalent with autosomes/trivalents were much more common: $50.37 \%$ (intraspecific hybrid) and $45.34 \%$ (interspecific hybrid) of the nuclei had these features (Figure 2K, Table S1 [4]). Examples of XX bivalent association with SC trivalents are presented in several of the Figures (intraspecific: Figure 2D-F and Figure S3A-C,E; interspecific: Figure $2 \mathrm{H}$ and Figure S4A,B). It should be emphasized that in interspecific hybrids, there were associations of one of the $\mathrm{X}$ axes with an autosome or trivalent by a thin CREST-positive linear link (Figure S4B,D), as well as an association through a ChB (Figure 3C).

\subsection{Free Closed SC Trivalents and Open SC Trivalents in Chains}

The intra- and interspecific hybrids differed in the number of formed free closed SC trivalents. Based on the karyotypes, we assumed that at the pachytene stage of both hybrids, 10 metacentrics and 20 acrocentrics should have formed 10 SC trivalents. However, in intraspecific hybrids, $1-4$ free closed SC trivalents were most often found (Figure 3A,B,G and Figure S3F). It should be emphasized that in single nuclei, we found 7 and 10 SC trivalents (Figure 3E,F and Figure S3C, H). In one of the animals, there were closed SC trivalents with SYCP3- and AgNO3-positive dense material in the region of the short arms of the acrocentrics (Figure $\mathrm{S} 3 \mathrm{H}, \mathrm{H}^{\prime}, \mathrm{H}^{\prime \prime}, \mathrm{I}, \mathrm{J}, \mathrm{J}^{\prime}, \mathrm{K}$ ) or in the pericentromeric region of SC trivalents (Figure S3L, $\mathrm{L}^{\prime}$ ). Open SC trivalents formed SC chains due to heterosynapsis between the short arms of acrocentrics (Figures S3A,B and S7).

Free closed SC trivalents, as a rule, were not detected in spermatocytes of interspecific hybrids (Figure 3E,F,K and Figure S4A,J,K,L, Table S1 [5]), i.e., they remained open and embedded in SC chains. There was one closed SC trivalent in $21 \%$ of nuclei (Figure $3 \mathrm{H}$ ), as well as in squashes (Figure S8). There were two (Figure 3C) or four (Figure 3D) SC trivalents in single cells (Figure 3F). In the chains of the SC trivalents, the centromeric sites of the metacentrics were strongly stretched (see Section 2.5).

\subsection{Stretched Centromeres in SC Trivalents and Their Participation in SC Trivalents Chains}

In the nuclei of cells from both hybrids, there was stretching of the centromeric regions of the metacentrics of the SC trivalents (intraspecific: Figure 3A,G; interspecific: Figure 3C,D,H,K). However, we only observed this phenomenon in $16 \%$ of pachytene cells from intraspecific hybrids, and their length was less than $3 \mu \mathrm{m}$ (Figure 3I,J). By contrast, in interspecific hybrids, we observed centromere stretching in 70\% of spermatocytes. In most cases the length was $>3 \mu \mathrm{m}$ (Figure 3I,J, Table S1 [6]), and in some nuclei it reached $\geq 10 \mu \mathrm{m}$ (for example, Figure $3 \mathrm{~K}$ ). In interspecific hybrids, the centromeric region of the metacentrics was strongly stretched (Figure $3 \mathrm{H}, \mathrm{K}$ and Figure $\mathrm{S} 4 \mathrm{~B}, \mathrm{~F}$ ). There was trivalent centromere stretching in zygotene spreads (Figure S5) and pachytene squashes (Figure S8). Squashes with preserved three-dimensional nuclear space confirmed that stretched centromeres were not an artifact of the spreading technique (Figure S8).

Of note, we detected centromere stretching in the acrocentrics of the SC trivalents, although less frequently than in metacentrics (Figure S6). This feature was shown in SC trivalents, which were part of SC chains (Figure S6A-G,I).

Thus, a comparison of the chains of SC trivalents allowed us to establish some differences between hybrids. In intraspecific hybrids, the connection between trivalents occurred due to the short arms of acrocentrics (heterosynapsis). In interspecific hybrids, the formation of such SC chains was accompanied by a strong stretching of the centromeric regions of the metacentrics and acrocentrics in $\mathrm{SC}$ trivalents, and neighboring SC trivalents can join due to the stretched centromeric regions of the acrocentrics (shown schematically in Figure S7 for both hybrids). 
In general, three main types of SC trivalents can be distinguished in mole vole hybrids (Figure 4). It should be noted that we identified centromere stretching by immunostaining with both polyclonal and monoclonal antibodies to centromere proteins obtained from different manufacturers (Figure S4A,J-L).

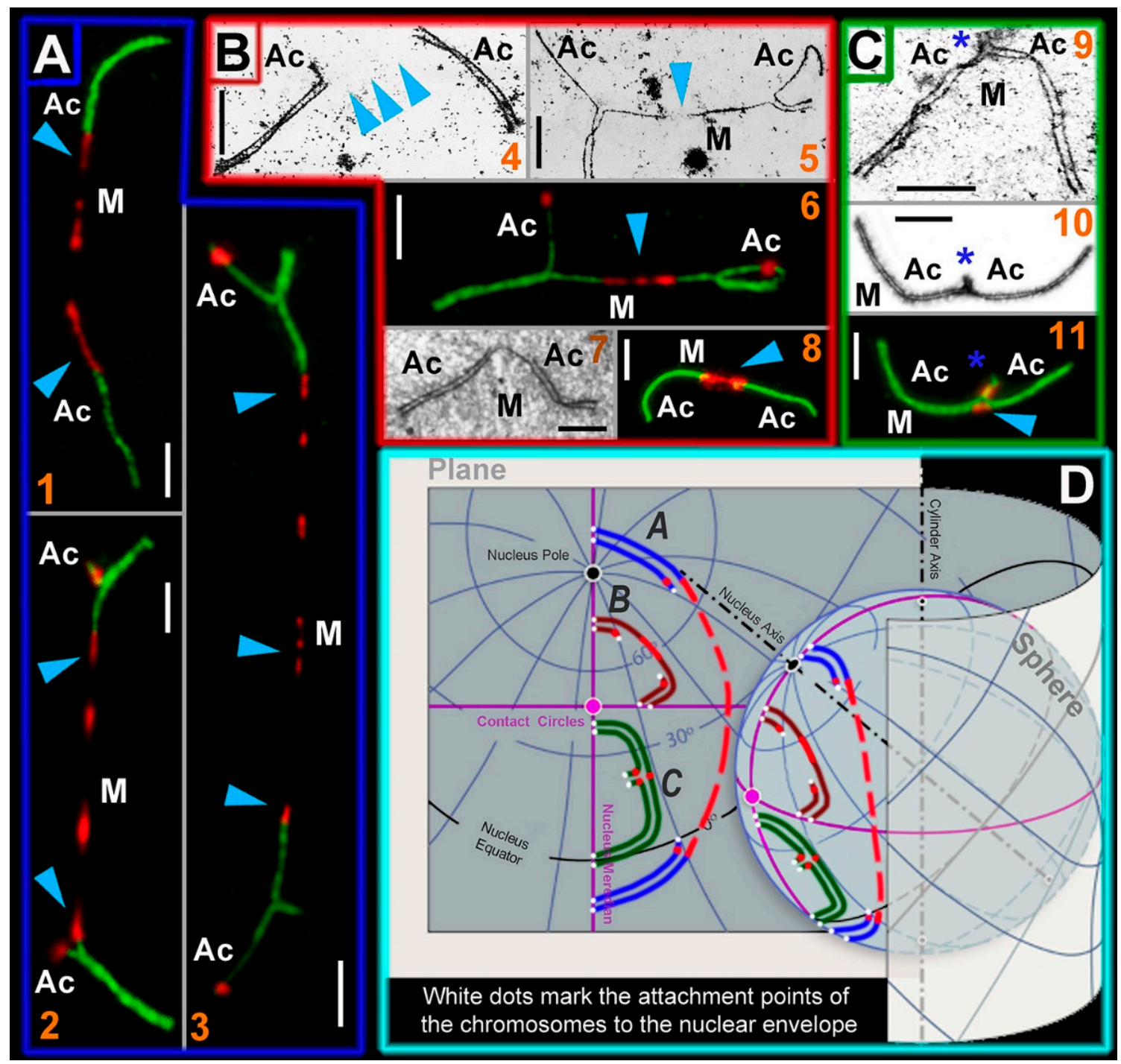

Figure 4. SC trivalent types of the Ellobius hybrids and their simulated location on a plane and a sphere. Light micrographs after immunostaining $(1,2,3,6,8$, and 11): SCs were immunostained with antibodies against SYCP3 (green) and centromeres-with an antibody to kinetochores (CREST, red). Electron micrographs after $\mathrm{AgNO}_{3}$-staining (4, 5, 7, 9, and 10): blue arrowheads show centromeric regions of metacentrics in SC trivalents. $M$ indicates metacentric and Ac indicates acrocentric. (A) SC trivalents elongated by centromeric region stretching in spermatocytes of the Etalpinus $\times E$ tancrei interspecific hybrid. The length of the centromeric region of metacentrics in such SC trivalents is $>3 \mu \mathrm{m}$. (1) SC trivalents in which short arms were not visible: if there were no immunostained centromeric regions, then the SC trivalents would be identified as two pseudobivalents. (2) SC trivalents with short arms of acrocentrics. (3) SC trivalents with very stretched centromere. As a rule, such SC trivalents stretch across the length of the entire nucleus (from one side to the other). (B) SC trivalents with short stretched centromeric regions ( $<3 \mu \mathrm{m}$ in length). This type of SC trivalent was found in all hybrids. (4) Two pseudobivalents that are part of the SC trivalent. (5) The metacentric in the SC trivalent has a 
gap, in which there is probably a stretched centromeric region. (6) SC trivalents like in 5; the stretched centromeres of the metacentric are visible. (7 and 8) Short SC trivalents with faintly distinguished short arms of acrocentrics and not very stretched centromeres. (C) Closed SC trivalents with clearly visible short arms of acrocentrics (blue stars) and dot-like centromeres (9-11): This type of SC trivalent is found in all hybrids. (D) Simulation of SC trivalents on a plane and a sphere. SC trivalents of $A$ type (see panel A) have far-reaching attachment points to the nuclear envelope and long stretched centromeric region with gaps. SC trivalents of $B$ and $C$ types (see panels $\mathbf{B}$ and $\mathbf{C}$ ) are more compact and do not have long stretched centromeres. Scale bars represent $5 \mu \mathrm{m}$.

\subsection{Bivalent \#7 Behavior}

Chromosome \#7 is an excellent karyotypic marker, and it can be used to identify both intraand interspecific hybrids. Based on previous research, the submetacentric in E. tancrei is formed due to the neocentromere formation established by SCs analyses $[60,61]$ and then supplemented by Zoo-FISH data [50]. In interspecific hybrids, this chromosome pair appears as an SC bivalent with two centromeres, because an acrocentric homolog (E. talpinus) and a submetacentric homolog (E. tancrei) entered into synapsis. In the vast majority of nuclei in both hybrids, SC \#7 was easily identified (Figures 2 and 3, Table S1 [7]). There was only a clear association of the SC chromosome \#7 bivalent, or rather its acrocentric homolog, with the SC trivalent (Figure S4E).

\subsection{Chromosome Recombination}

We studied meiotic recombination in Ellobius parental species and hybrids using the MLH1 protein, a marker of crossovers. The average number of MLH1 foci per nucleus is an important recombination parameter. It can be used to compare closely related species, in homozygous and heterozygous forms [24], as well as to examine recombination in larger taxa [62]. In the latter case, the haploid number of autosomes (NFha) and the haploid number of autosomal arms (NFha.a) are considered.

The number of MLH1 foci per nucleus $(\mathrm{M} \pm \mathrm{SD})$ was $23.48 \pm 3.3$ in E. talpinus $(2 n=54, \mathrm{NF}=54$; $\mathrm{NFha}=26$, NHha.a = 26), $23.1 \pm 3.1$ in E. tancrei $(2 \mathrm{n}=54, \mathrm{NF}=56$; NFha $=26$, NHha.a $=27)$, and $22.8 \pm 3.7$ in E. tancrei $(2 n=34, \mathrm{NF}=56$; NFha $=16$, NHha.a $=27)$ (Figure 5A-C). These rates were not significantly different among species (Table S1). The number of MLH1 foci in all species was slightly lower than the NFha.a values. Thus, not every chromosome arm has at least one MLH1 signal. We previously described detection of MLH1 signals in the XX bivalent; the rate was $46 \%$ for E. talpinus and $65 \%$ for E. tancrei $(2 n=54)[59]$.

The average number of MLH1 signals was $15.4 \pm 4.4$ for the intraspecific hybrid $(2 n=44, \mathrm{NF}=$ 56 ; NFha $=21$, NHha.a $=27)$ and $14.8 \pm 4.7$ for the interspecific hybrid $(2 n=44, \mathrm{NF}=55$; NFha $=21$, NHha.a $=26.5$ ) (Figure 5D,E). These rates differed significantly between the hybrids and compared with the parents (Table S1) and were significantly lower than the NHha.a number. A decrease in the recombination level in hybrid spermatocytes was due to the formation of chains of SC trivalents, where the arms of acrocentrics did not have a complete synapse with the arms of metacentrics. 


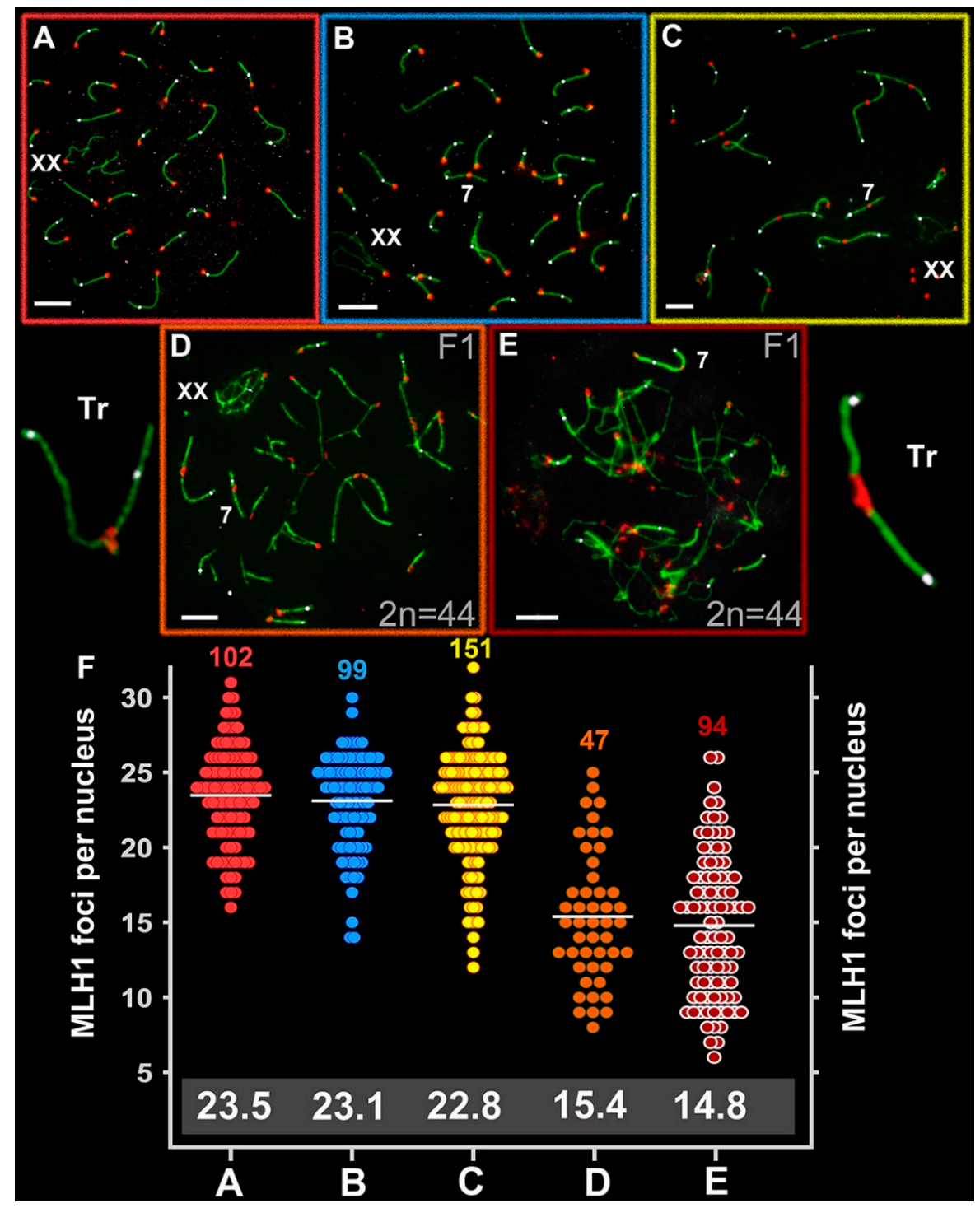

Figure 5. Recombination in Ellobius species and hybrid males. Axial elements were identified using anti-SYCP3 antibodies (green), kinetochores using CREST antibodies (red), and anti-MLH1 (white) was used as a marker of recombination nodules. (A) E talpinus $(2 n=54, \mathrm{NF}=54)$; (B) E. tancrei $(2 n=54$, $\mathrm{NF}=56) ;(C)$ E. tancrei $(2 n=34, \mathrm{NF}=54) ;($ D) F1 E. tancrei $\times$ E. tancrei hybrid; (E) F1 hybrid E. talpinus $\times$ E. tancrei hybrid. (F) Comparison of MLH1 foci per nucleus in mole voles: the numbers above the dot diagrams correspond to the number of counted cells. White numbers in a gray frame correspond to the average number of MLH1 foci. Table S1 presents details on significant statistical differences between species and hybrids. Scale bars represent $5 \mu \mathrm{m}$.

\section{Discussion}

$\mathrm{Rb}$ translocations affect the genome by modifying gene positions and altering recombination during meiosis. Overall, our findings present experimental evidence supporting assumptions that chromosomal rearrangements redesign a genome and may contribute to speciation due to meiotic alterations in hybrids. We have demonstrated that hybrids with the same diploid number and identical chromosome combination could be sterile (interspecific) or have reduced fertility (intraspecific), a condition that is in line with the behavior of chromosomes in meiosis. Despite the fact that both types of hybrids had similar irregularities during prophase I, there were different synaptic patterns in SC trivalents, especially specifics of centromeric segments. We hypothesize that these differences originated due to altered meiotic architecture and could to be responsible for the species divergence. 


\subsection{Chromosome Synapsis Instability and Reduced Recombination in Hybrids}

There is a huge amount of data and knowledge that allows us to unambiguously state that hybrids possess distinct patterns of chromosomal synapsis and recombination compared with their parents, which have a significant evolutionary output $[35,63,64]$. Intra- and interspecific mole vole hybrids with 10 trivalents showed variation in fertility, as has been shown for heterozygous lemurs. Indeed, the first known case of hybrids with numerous $\mathrm{Rb}$ chromosomes was described for lemurs [65]. At that time, researchers believed that hybridization occurred between lemur subspecies [66]. According to the modern taxonomy $[67,68]$, interspecific lemur hybrids were studied in 1988. Lemurs with 3-6 trivalents had fertility similar to their parents, while lemurs with eight trivalents had reduced fertility $[65,66]$.

The first group of lemurs did not have any associations of bivalents and trivalents with each other and with XY. The second group regularly demonstrated chains of SC trivalents, combined by heterosynapsis of the short arms of acrocentrics, and association with the sex bivalent [66]. A large number of trivalents were likely unable to complete synapsis in time, and this deficit could lead to aberrant chromosome segregation, arrest of cells at M1 or M2 stages, germ cell aneuploidy, and decreased fertility. We observed the synapsis delay for SC trivalents in intraspecific mole vole hybrids; this finding is consistent with previous studies [45,53]. However, in contrast to lemur hybrids, in intraspecific mole vole hybrids, there were often gaps in the axial elements of the metacentrics in open SC trivalents $[45,53]$. Based on immunostaining, now we interpret such specific gaps as stretching of the centromeric regions.

Mus musculus domesticus that were heterozygous for $\mathrm{Rb}$ metacentrics were also highly variable in their fertility $[57,69]$. Thus, in some intraspecific mice hybrids, for example, heterozygous for three $\mathrm{Rb}$ translocations, there was no decrease in fertility, although there were "XY-trivalent" and "trivalent-trivalent" associations [70]. In other cases, comparative analysis revealed differences in fertility level due to distinct karyotype structures: a slight decrease (four SC trivalents) and a significant decline in fertility (seven SC trivalents) [71]. Possibly, the difference was due to higher associations of SC trivalents with sex XY bivalent and associations of trivalents with each other in animals of the second group.

In other experiments, fertile hybrids heterozygous for eight $\mathrm{Rb}$ translocations had open and closed SC trivalents [72]. The authors suggested that the meiotic progression of cells with an asynaptic area of SC trivalents was due to the insignificant genetic value of the unsynapsed chromatin regions, the inactivation of which did not lead to the activation of the pachytene arrest program.

Hybridization of different forms of the musk shrew (Suncus murinus) could lead to the formation of five SC trivalents in meiocytes. Some of the F1 hybrids were sterile, while others were fertile, depending on different parental combinations. Researchers have suggested that genetic factors play a crucial role in determining fertility/sterility [73,74]. In the case of mole vole hybrids, animals regularly had impaired fertility (intraspecific) or were sterile (interspecific), although this fact does not exclude the effect of unknown genetic factors in determining the fertility level.

Alterations in recombination might be crucial for species evolution $[75,76]$. Physical problems in the synapsis of rearranged homologs can restrict the formation of recombination sites [77,78], which can lead to univalence, unbalanced chromosome segregation and selection of germ cells [79-81]. Comparison of distinct mole vole hybrids reliably demonstrated that recombination was reduced in hybrids, a phenomenon that was most likely correlated with a delay in synapsis of SC trivalents or their physical stretching. It is likely that some of the achiasmatic chromosomes in trivalents can be incorrectly segregated, and such cells will be eliminated in meiotic checkpoints [82].

\subsection{Centromere Identity and Stretched Centromeres of the SC Trivalents}

Centromeres are unique chromosomal regions that organize the assembly of the kinetochore, a large multiprotein complex that allows chromosomes to attach to spindle microtubules and move during mitotic and meiotic cell division $[83,84]$. There is no universal DNA sequence responsible for centromere formation. This fact, and the emergence of new centromeres, led to the hypothesis that centromeres are 
determined by accumulation of tandem repeats (satellite DNA) [85-87] and retrotransposons [88,89] alongside epigenetic modifications such as histone variants $[90,91]$. The centromere-specific variant of histone H3, CENPA, is a platform for protein assembly at the kinetochore [92,93]. The rapid diversification of centromeres has been suspected to lead to reproductive isolation between species [85]. The position of the centromere is easily identified by routine staining; in immunostaining centromeres typically appear as one-spotted signals within chromosomes.

In mole voles, closed SC trivalents developed three contact points with the nuclear envelope: (1) the attachment point of the proximal ends of acrocentrics, formed by their short arms, and (2 and 3) two attachment points of the distal telomeres of metacentrics and acrocentrics (see Figure 3F). As prophase I progresses, the attachment points move away from each other; therefore, SC trivalents can have different spatial configurations [94]. However, open SC trivalents must be associated with the nuclear envelope at four points. In addition, acrocentrics were ectopically connected by short SCs with neighboring acrocentrics. There were multiple interlockings in interspecific mole vole hybrids. All these specifics caused the strongest tension of chromosomes involved in SC trivalents, stretching of the centromeric regions of the $\mathrm{Rb}$ metacentrics, and in some cases, the centromeric regions of the acrocentrics.

We used different antibodies against kinetochore proteins to identify centromeric regions of meiotic chromosomes in mole vole parental species and hybrids (Figure S4). As noted above, we observed 3 types of SC trivalents in hybrid spermatocytes (Figure 4). Thus, the distance between the attachment points determined the ultrastructural organization of SC trivalents. These attachment points were most clearly manifested in closed free SC trivalents (Figure $4 \mathrm{C}$ ). If the distance between the attachment points of the SC trivalent to the nuclear envelope was markedly greater than the metacentric length, then the metacentric axis undergoes strong stretching, and this did not allow the formation of a continuous axial element. Therefore, electron microscopic examination revealed a gap in the structure of the stretched axial element of the metacentric (Figure 4B). However, when immunostaining with antibodies to kinetochore proteins (ACA, CREST, and CENPA), there were no gaps, and a centromeric linear structure was visible in this area (Figure 4B). If the attachment points were located very far from each other (on different sides of the nucleus), then the centromeric region was hyperstretched up to gaps (Figure 4A).

Such stretched centromeres are intriguing because no similar regions have been found within SC trivalents before the present study. It is possible that these centromeric stretches are associated with the structural specifics of the pericentromeric chromatin. Chromatin in the centromeric region has the classic epigenetic marks of constitutive heterochromatin: H3K9me2, H3K9me3, H3K27me3, and H4K20me3 [95,96]. For example, in the study of unfolded pericentromeric heterochromatin (prekinetochores) in interphase, chromosomes subjected to stretching by TEEN buffer, there was alternation of the CENPA and H3K9me3 subdomains with the gaps [97]. If any natural or artificial extension does not lead to structural breaks, it likely entails a linear spatial unfolding of the structural components of pericentromeric heterochromatin. This phenomenon probably explains why we saw an alternating change of centromeric points, centromeric lines, and gaps in the metacentrics of SC trivalents. This feature might indicate high plasticity of mole vole pericentromeric heterochromatin.

Stretching of the centromeric regions of acrocentrics between SC trivalents is even more mysterious. This phenomenon was rarer than centromeric stretching of metacentrics. We suppose that this may also be due to a special stretching of the pericentromeric heterochromatin of the acrocentric short arms associated in chains of several SC trivalents. Moreover, heterochromatin was involved in the nonhomologous synapsis of the short arms of the acrocentrics of SC trivalents and in binding to the nuclear envelope in intraspecific hybrids (Figure S9). The centromeric associations of SC trivalents are of particular interest (see "Nuclear architecture: simulated chromosome configurations in mole vole pachytene spermatocytes" below).

In general, the presence of stretched centromeric regions may indicate specific properties of centromeres in the genus Ellobius. Stretched centromeres in bivalents as a likely result of $\mathrm{Rb}$ chromosome 
fusion have been identified in African pygmy mouse [98]. Centromeric satellites in animals and plants undergo rapid evolution [85], and they may differ even in closely related species [99-101]. These differences have been explained by the "library hypothesis" [102]: an ancestral form has an initial satellite pool ("library" of satellites), which in different evolutionary lineages manifests in various patterns (in quantity and quality), thus forming species-specific satellite profiles [103]. The hypothesis is supported by some examples [104]. In addition, it has been established that closely related species may differ in their retrotransposons. A classic example is a well-studied kangaroo. In interspecific kangaroo hybrids, there was centromere destabilization, which was caused by the activation of resident retroelements (in this case, kangaroo endogenous retrovirus (KERV)) $[88,105,106]$.

It would seem that such important chromosome elements like centromeres should be conserved, but they exhibit incredible structural and functional variability and dynamic evolution and are hotspots for chromosomal rearrangements [20,107]. The main remaining issues include the question of the true reasons for the centromeric region stretching in Ellobius hybrids as well as the molecular mechanisms of their striking plasticity. The study of centromeric satellites and retrotransposons in the Ellobius genus will be promising. It is obvious that additional detailed study of centromeric regions in Ellobius, including stretched centromeres and different centromeric localization of the heteromorphic chromosome \#7 pair in interspecific hybrids, will be necessary. The centromere features established here and data from previous works $[50,52,60,61]$ may suggest that the centromeres in mole voles, if not a driver of chromosomal evolution, are essential for karyotypic divergence.

\subsection{Chromosome \#7: Implications from the Hybrid Meiotic Nuclei Studies}

As mentioned above, the parental 54-chromosome karyotypes of E. talpinus and E. tancrei differ in only one pair of chromosomes (\#7). In these species, chromosome \#7 pairs were identical in G-bands, but in E. talpinus it is an acrocentric, and in E. tancrei it is a submetacentric. For a long time, it was assumed that the submetacentric emergence was due to pericentric inversion [108]. However, the SC study in interspecific hybrids clearly showed that this chromosome pair is completely synapsed without inversion loops, forming a full-length SC along the entire chromosome at the early-to-mid pachytene stage. We previously suggested that the submetacentric in E. tancrei emerged through the neocentromere formation $[60,61]$. This assumption was confirmed by additional Zoo-FISH data [50], and later by immuno-identification of the central element of SCs and recombination nodules [52].

The chromosome \#7 pair was used as a marker bivalent in the SC analysis. In interspecific hybrids, this was the only heteromorphic SC bivalent with two centromeres located at a distance from each other. Of note, we discovered another remarkable property of the SC \#7. In both hybrids, bivalent \#7 practically does not participate in chromosome associations: There was only one association of this chromosome with the open SC trivalent (Figure S4E). We assume that the inertness of chromosome \#7 in meiosis may be due to the absence or extremely low content of constitutive heterochromatin. This was confirmed using antibodies to histone $\mathrm{H} 3 \mathrm{~K} 9 \mathrm{me} 3$, a marker of constitutive heterochromatin, both in bivalent \#7 in E. tancrei (unpublished) and in a sibling species E. alaicus [109].

Thus, the ancestors of modern E. tancrei and E. alaicus, concomitant with the emergence of the neocentromeric submetacentric chromosome \#7 pair, probably acquired chromosomal instability with the formation of various karyotypic forms, which may indicate some causal link between these events. Perhaps one of them could become an evolutionary trigger, which entails a chain of genetic and/or cytogenetic changes in the mole vole karyotype.

\subsection{Nuclear Architecture: Simulated Chromosome Configurations in Mole Vole Pachytene Spermatocytes}

The organization of the internal contents is not random in interphase $[110,111]$ and meiotic [112] nuclei; therefore, it is customary to speak of nuclear architecture [113] or intranuclear landscape [114]. The "chromosome territory" concept is considered to be generally accepted [115]. Chromosome territories are spatial domains of different sizes that specifically occupy a certain volume in the nucleus [116]. The position of chromosomes in the nucleus can be preserved in closely related 
taxa [117], a phenomenon called "phylogenetic memory" [118]. Heterochromatic compartments play a significant role in the nucleus content [119]. However, gene mutations and chromatin and chromosomal rearrangements can change the intranuclear organization, which can lead to diseases and the appearance of various abnormal manifestations [120-125].

There is also a point of view, according to which the correct formation of chromosome territories diminishes the translocation potential of the cells [126]. The organization of interphase and meiotic nuclei has significant differences [127]. An SC forms a specific chromatin pattern [128] and interacts with the nuclear envelope through a special Sun-KASH system [129]. The presence of asynaptic chromosome regions in prophase I initiates a meiotic silencing of unsynapsed chromatin (MSUC) [130,131]. Nuclear architecture of prophase I meiocytes is specific for each species [132-134].

As a result, the nuclear architecture in meiotic prophase I is determined by the SC structure and dynamics, types of chromosomes (single-armed or bi-armed), their length, the heterochromatin amount, the specificity of centromeric regions, the "chromosome-nuclear envelop" interactions, the ability to form chromocenters and nucleoli, and sex chromosome organization and behavior [134]. It should be emphasized that if the parental genomes differ significantly, then complex chromosome compounds are formed in hybrid and mutant meiotic nuclei (for example, [21,135-137]), and the processes of repair, recombination, and meiotic silencing are disrupted (for example, [24,138-140]), which can cause an imbalance in the nuclear architecture.

In two hybrid mole vole groups, a different number of free closed SC trivalents formed. Pericentromeric heterochromatin likely played an important role in the formation of closed trivalent configurations, as described in heterozygous mice [94]. Thus, on the three-dimensional nuclei of interspecific mole vole hybrids, there were closed SC trivalents, which were attached by the short arms of acrocentrics to the nuclear envelope, and open SC trivalents with stretched centromeric regions (CREST cloud around) (Figure S8). CREST antibodies can non-specifically immunostain heterochromatic regions and heterochromatin-like structures, for example, ChBs (Figures 2H and 3D). The same specificity was revealed during the electron microscopic examination of the intraspecific heterozygous spermatocytes. At the attachment site of the short arms of the SC trivalent, a cloud of electron-dense material formed, associated with the nuclear envelope, which was usually interpreted as heterochromatin mass (Figure S9, schemes of hemispheres in Figure 3F).

SC trivalent chains were demonstrated in intraspecific mole vole hybrids $[45,53]$. Such ectopic associations formed due to the heterochromatic contacts of the short arms of acrocentrics of two different open SC trivalents (Figure S7), as had been noted earlier [46]. Chromosome associations can be determined by $\mathrm{H} 3 \mathrm{~K} 9 \mathrm{me} 3$ immunodetection [94]. This protein is believed to mark DAPI-positive chromocenters (for example, [141]). However, chromocenters in all mole voles were usually not detected by DAPI staining. Nevertheless, we found that acrocentric chromosomes were grouped by their pericentromeric regions around the H3K9me3 domains in the sibling species E. alaicus [109]. We saw a similar grouped position of acrocentrics in E. talpinus (Figure 2A). In E. tancrei $(2 n=34)$, the centromeric sites of the acrocentrics were also located around the H3K9me3 clouds, while these sites of the $\mathrm{Rb}$ metacentrics had a more linear form of the H3K9me3 signals, as seen in the micrographs (Figure S9A, $\mathrm{A}^{\prime}$ ).

Combining the results on the ultrastructure and behavior of SCs and SC trivalents in spreads and squashes, we present these data as three-dimensional simulations of chromosome configurations in the meiotic nuclei of mole vole parental species and hybrids (Figure 6). 

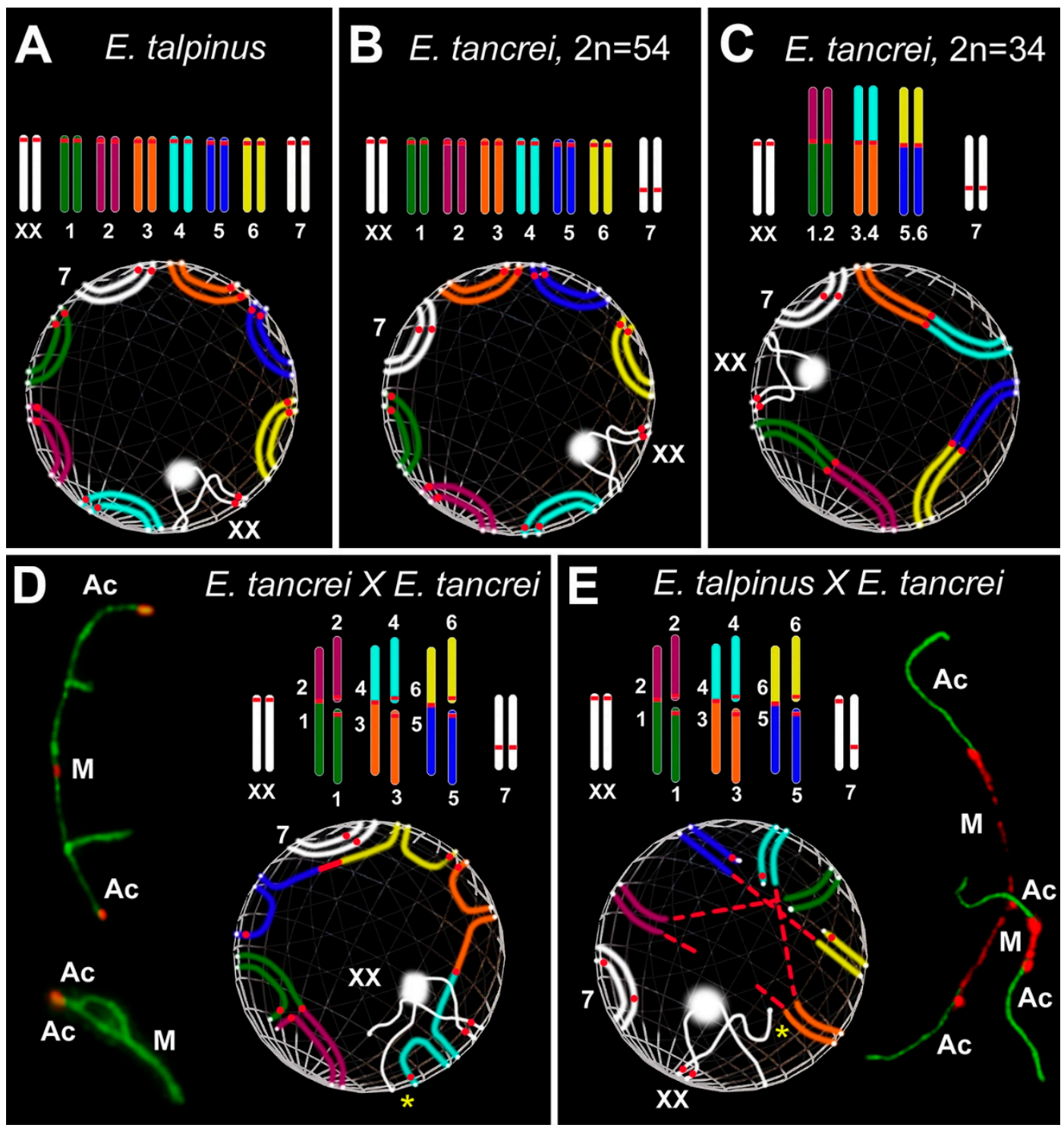

Figure 6. Simulation of chromosome synapsis and interactions of SC trivalents in pachytene nuclei of Ellobius species and hybrids. A partial set of chromosomes and lower-inside the spheres-features of the configuration of the axial elements of these chromosomes during synapsis at the pachytene stage are presented in each part of the Figure. White dots at chromosome ends mark the attachment points of the chromosomes to the nuclear envelope. $\mathrm{M}$ indicates metacentric and Ac indicates acrocentric $(\mathrm{D}, \mathrm{E})$. (A,B) Chromosomes: Seven pairs of autosomes and a pair of isomorphic sex (XX) chromosomes in A and B. The chromosome sets differ from each other only in the chromosome 7 pair: acrocentric in Ellobius talpinus $(2 n=54)$, neocentromeric submetacentric in Ellobius tancrei $(2 n=54)$. Spheres: The positions of SCs over the nuclear envelope in the pachytene nuclei in A and B are different, because it is assumed that chromosome territories can be distinguished between two species [94,134]. (C) Chromosomes: Conditional karyotype of E. tancrei $(2 n=34)$ consists of three pairs of homologous Robertsonian $(\mathrm{Rb})$ metacentrics $(1.2,3.4$ and 5.6), a submetacentric chromosome \#7 pair and sex (XX) chromosomes. Sphere: The chromosomal arms of metacentrics do not always occupy the ancestral position (compare spheres A, $\mathrm{B}$, and $\mathrm{C}$ ), because $\mathrm{Rb}$ metacentric formation causes a shift in the chromosome territories in the meiotic nucleus (see [94,120]). (D) Chromosomes: Karyotype of the intraspecific hybrid E. tancrei obtained from crossing two forms $(2 n=54$ and $2 n=34)$. The scheme of partial karyotype shows three Rb metacentrics $(1.2,3.4,5.6)$ and six acrocentrics (1-6). Sphere: Three Rb metacentrics and acrocentrics form three SC 
trivalents. They are attached to the nuclear envelope and part of them remains open for a long time at the mid pachytene. The synapsis of chromosomes in all SC trivalents is gradually completed to the diplotene, which will ensure their correct segregation in the future. Open and closed SC trivalents are presented on the left. (E) Chromosomes: Karyotype of the sterile interspecific hybrid obtained from crossing two species E. talpinus $(2 n=54)$ and E. tancrei $(2 n=34)$. The scheme of partial karyotype shows three $\mathrm{Rb}$ metacentrics (1.2, 3.4, and 5.6) and six acrocentrics (1-6) like the intraspecific hybrid (D). Sphere: The main difference in the chromosome synapsis in SC trivalents is that the centromeric regions of the metacentrics are very stretched. The centromeric regions of acrocentrics are also stretched in some cases. Centromere stretching is associated with the difference in chromosome territories of two parent species. SC trivalents with stretched centromeres are presented on the right. Associations of sex chromosomes with SC trivalents (yellow stars) are often observed in both hybrids. Chromatin dense bodies (ChBs) of $\mathrm{XX}$ bivalents are a white ball on one of the $\mathrm{X}$ axes.

\section{Materials and Methods}

\subsection{Animals}

All Ellobius males were obtained from a mole vole collection of the IDB RAS. For meiotic studies, the parental Ellobius forms: three E. talpinus, two E. tancrei $(2 n=54)$, five E. tancrei $(2 n=34)$ and two groups of F1 hybrids: three intraspecific hybrids $E$. tancrei $\times E$. tancrei, five interspecific hybrids $E$. talpinus $\times$ E. tancrei were used in this work.

The fertility of parental forms and hybrids was determined based on relevant data: 66 pups and 23 litters in E. talpinus, 168 pups and 71 litters in E. tancrei $(2 n=54), 197$ pups and 82 litters in E. tancrei $(2 n=34), 41$ pups and 20 litters of the intraspecific hybrid F1 E. tancrei $\times$ E. tancrei, 93 pups and 24 litters of the interspecific hybrid F1 E. talpinus $\times$ E. tancrei.

\subsection{Ethics Statement}

Experimental procedures were performed in strict accordance with the international, national, and institutional guidelines for animal care. Studies were approved by the Ethics Committee for Animal Research of the Vavilov Institute of General Genetics RAS (order №3 of 10 November 2016) and the Koltzov Institute of Developmental Biology RAS (Annual permissions, 2013-2017).

\subsection{Spermatocytes Suspensions}

The removed testes were exempted from tunics, large blood vessels and fat. A piece of testis tissue was placed on a cavity slide in $1 \mathrm{ml}$ of Eagle's medium (without glutamine), $37^{\circ} \mathrm{C}$ (Paneco, Moscow, Russia). The testis tissue was crushed with razor blades, then the cell suspension was homogenized using an automatic pipette for 10-15 min. The degree of homogenization of the suspension and its cell composition was controlled under a light microscope Axioskop 40 (Carl Zeiss, Jena, Germany).

\subsection{Spermatocytes Spreads}

Spermatocyte spreads were obtained in accordance with the procedure of Kolomiets et al. [46,142]. An amount of $5 \mu \mathrm{L}$ of testis cell suspension in Eagle's medium was applied to the surface of the convex meniscus of a drop $(20 \mu \mathrm{L})$ of $0.2 \mathrm{M}$ sucrose solution (hypophase). The cells swelled up and then spread over the surface of the hypophase. After $1 \mathrm{~min}$, a slide with a polylysine or coated with an electronically transparent chemically resistant film is touched to the surface of the hypophase (a $0.5 \%$ solution of the fragments of Falcon dish in chloroform). Cells adhering to the film surface were fixed with a $4 \%$ solution of paraformaldehyde, $\mathrm{pH} 8.0-8.4$, washed with a $0.4 \%$ solution of Photoflo (Kodak, Rochester, NY, USA), pH 8.0, and dried in air. 


\subsection{Spermatocytes Squashes}

As emphasized by Berrios et al. [141], squashes allow to preserve chromatin condensation and organization (3D space) of nuclei. Spermatocyte squashes were prepared in accordance with the procedure of Page et al. [143] (personal training from Jesus Page and Ana Gil-Fernandes in 2017). Removed testes were fixed in 2\% formaldehyde in PBS with 0.05\% Triton X-100 during $10 \mathrm{~min}$. Then, several pieces of the seminiferous tubules were placed on a slide and squashed by exerting pressure on the coverslip. The slides were immersed in liquid nitrogen and the coverslips were removed with a knife. The slides were washed in PBS for 15 minutes and were immunostained.

\subsection{Antibodies and Immunocytochemistry}

The slides were washed in PBS. Spreads and squashes were blocked with HB (holding buffer: PBS, $0.3 \%$ BSA, $0.005 \%$ Triton X-100). The slides were incubated overnight at $4{ }^{\circ} \mathrm{C}$ with primary antibodies: rabbit polyclonal antibodies SCP1 (Abcam, Cambridge, UK), rabbit polyclonal antibodies SCP3 (Abcam, Cambridge, UK) both diluted to a concentration of 1:500 in ADB (Antibody Dilution Buffer: PBS, 3\% BSA, 0.05\% Triton X-100), mouse antibodies MLH1 (1:50, Abcam, Cambridge, UK), mouse anti-phospho-histone H2AX (1:1000, Abcam, Cambridge, UK), human anti-centromere antibodies CREST (Fitzgerald Industries International, Concord, MA, USA), ACA (Antibodies Incorporated, Davis, CA, USA) or monoclonal CENPA (Abcam, Cambridge, UK), all diluted to a concentration from 1:200 to 1:400 in ADB. The slides were washed in PBS and incubated with goat anti-rabbit Alexa Fluore 488 conjugated antibodies (1:500, Abcam, Cambridge, UK), goat anti-human Alexa Fluore 546 conjugated antibodies (1:200-1:400) and goat anti-human Alexa Fluore 546 conjugated antibodies (1:500) at $37^{\circ} \mathrm{C}$ for two hours. The slides were washed with PBS, rinsed briefly with distilled water, dried and mounted in Vectashield with DAPI (Vector Laboratories, Burlingame, CA, USA). For some details of immunocytochemistry procedures, see [59]. The slides were analyzed with an Axioimager D1 microscope CHROMA filter sets (Carl Zeiss, Jena, Germany) equipped with Axiocam HRm CCD camera (Carl Zeiss), and image-processing AxioVision Release 4.6.3. software (Carl Zeiss, Jena, Germany). Images were processed by Adobe Photoshop CS5 Extended.

\subsection{AgNO3-Staining and Electron Microscopy}

The slides were stained with $50 \%$ AgNO3 solution in a humid chamber at $56{ }^{\circ} \mathrm{C}$ for 3 hours. The slides were washed in four changes of distilled water and air-dried. The stained slides were observed in a light microscope Axioskop 40 (Carl Zeiss, Jena, Germany), suitably spread cells were selected, and plastic (Falcon film) circles were cut out with a diamond tap and transferred onto grids. The slides were examined under JEM 100B or JEM 1011 electron microscope (JEOL, Tokyo, Japan).

\subsection{Histological Analysis of Testis Sections}

Testes were removed, fixed overnight in Bouin's solution, and then stored in $70 \%$ ethanol until use. The fixed testes were dehydrated in a graded ethanol series, immersed sequentially in ethanol/xylene and xylene, and then embedded in paraffin. The testes were sectioned at a thickness of $6 \mathrm{~mm}$ and mounted on glass slides. The sections were deparaffinized and stained with hematoxylin and eosin.

\subsection{Statistical Analysis}

The statistical analysis of all data was performed using GraphPad Prism 8 software (San Diego, CA, USA). Mean values (M) and standard deviation (SD) were calculated by the descriptive option of the software. P-values reported in Table S1 were calculated by Mann-Whitney two-sided non-parametric test. Bar charts, ring and dots diagrams were created by graph options of the software. 


\section{Conclusions}

Hybridization manifests a wide range of selective mechanisms, including decreased fertility or even sterility, due to defective synapsis and recombination $[78,144,145]$, meiotic silencing failure $[139,140]$, unbalanced chromosome segregation [80], and alteration of nuclear architecture [120]. Modification of the nuclear architecture can be demonstrated by comparing native (parental) and experimental hybrids. The 34-chromosome mole voles differ in the positions of the chromosomal territories compared with the native 54-chromosome form due to $10 \mathrm{Rb}$ pairs. To assess the differences in the location of chromosome territories, we performed experimental hybridization of 54- and 34-chromosome mole voles. We obtained two types of heterozygous mole voles with the same diploid number and identical chromosomal combinations. These two models are different in the manifestation of their fertility: intraspecific hybrids have slightly reduced fertility while interspecific hybrids are sterile. Forming the same number of SC trivalents, germ cells of the heterozygotes showed a different behavioral spectrum of chromosome combinations. In both hybrids, SC trivalents formed SC chains. However, in intraspecific hybrids, SC trivalents were able to leave such associations and form closed configurations, while in interspecific hybrids, only a few (usually 1-2) trivalents could complete the synapsis. The remaining SC trivalents could not dissociate from the SC chains, probably due to the peculiarities of the organization of centromeric regions in SC trivalents. The degree of nuclear architecture reorganization in the two hybrids was different, although the chromosome combinations were identical. These results suggest that alterations of nuclear architecture depend not only on the chromosome composition but also on other genetic or/and epigenetic factors.

Given that the behavior of the centromeric regions of SC trivalents was different in the two types of mole vole hybrids, it was logical to assume that this specificity could at least powerfully contribute to reproductive breakdown or be considered a cause of the sterility of interspecific hybrids. Because centromeres can be associated with patterns of gene expression and chromatin modifications [146], physically stretched centromeric regions (as an indicator of nuclear architecture reorganization) could indirectly modify or destabilize these processes. Thus, we hypothesize that the shift in the intranuclear organization and the centromere stretching could change genetically significant regions of the genome through chromatin reformatting or altering the patterns of gene expression, which, in turn, could provoke the activation of meiotic checkpoints.

We suppose that pachytene irregularities and decreased recombination could synergistically, along with centromere instability and reorganization of intranuclear contents, contribute to the complete sterility of interspecific mole vole hybrids. In intraspecific hybrids, synaptic irregularities and a reduced crossover number could reduce fertility, but only in the F1 generation; future generations demonstrated ordinary fertility [47]. The role of genetic factors in the development of sterility cannot be ruled out, because "hybrid sterility genes directly or indirectly modulate the sensitivity of synapsis to the sequence divergence between heterospecific chromosomes, either enhancing or suppressing it" [24].

Summarizing our findings and previous studies, we conclude that a unique group of subterranean rodents, mole voles from the genus Ellobius, exhibits a wide range of interesting chromosomal phenomena, such as different systems of sex chromosomes, heterology of two isomorphic male $\mathrm{X}$ chromosomes, expressed in asynchronous chromatin inactivation at prophase $\mathrm{I}$, multiple $\mathrm{Rb}$ translocations and monobrachial homologous metacentrics, neocentromere formation, stretched centromeres, acrocentric interactions leading to the formation of dicentric chromosomes and new $\mathrm{Rb}$ chromosome emergence. Each of the events could be considered as a driver or trigger of the karyotypic evolution of the rodents.

Supplementary Materials: Supplementary materials can be found at http://www.mdpi.com/1422-0067/21/20/ 7630/s1.

Author Contributions: Maintenance of mole vole collection, hybridization, fertility data and karyotyping of Ellobius species and hybrids were performed by I.B. All meiotic studies and calculation of gonadosomatic indices were carried out by S.M., A.T., A.K. and O.K. Conceptualization of all meiotic researches of mole voles and its 
performing were supervised by O.K. The visualization and presentation of all data and images design were done by S.M. The primary original draft of the manuscript, including Supplementary materials, was written by S.M. and O.K. All the authors read, discussed, modified and approved the final text of the submitted manuscript and the supporting information. All authors have read and agreed to the published version of the manuscript.

Funding: This research was supported by the research grant of the Russian Foundation for Basic Research No 20-34-70027 (S.M., A.T., A.K.) and VIGG RAS State Assignment Contract, No 0112-2019-0002 (S.M., O.K.); and by the Russian Foundation for Basic Research No 20-04-00618 (I.B.) and IDB RAS State Assignment for Basic Research, No 0108-2019-0007, 2020 (I.B.). Each of the two RFBR grants supported only those parts of the work for which each of the co-authors contributed.

Acknowledgments: We thank the Genetic Polymorphisms Core Facility of the VIGG RAS, Moscow, for the possibility to use their microscopes. We thank S. Kapustina and V. Tambovtseva from IDB RAS for their help in maintaining the mole vole collection. We are grateful to GN Davidovich and AG Bogdanov of the Electron Microscopy Laboratory of Biological Faculty of Moscow State University for their technical assistance.

Conflicts of Interest: The authors declare no conflict of interest. The funders had no role in the design of the study; in the collection, analyses, or interpretation of data; in the writing of the manuscript, or in the decision to publish the results.

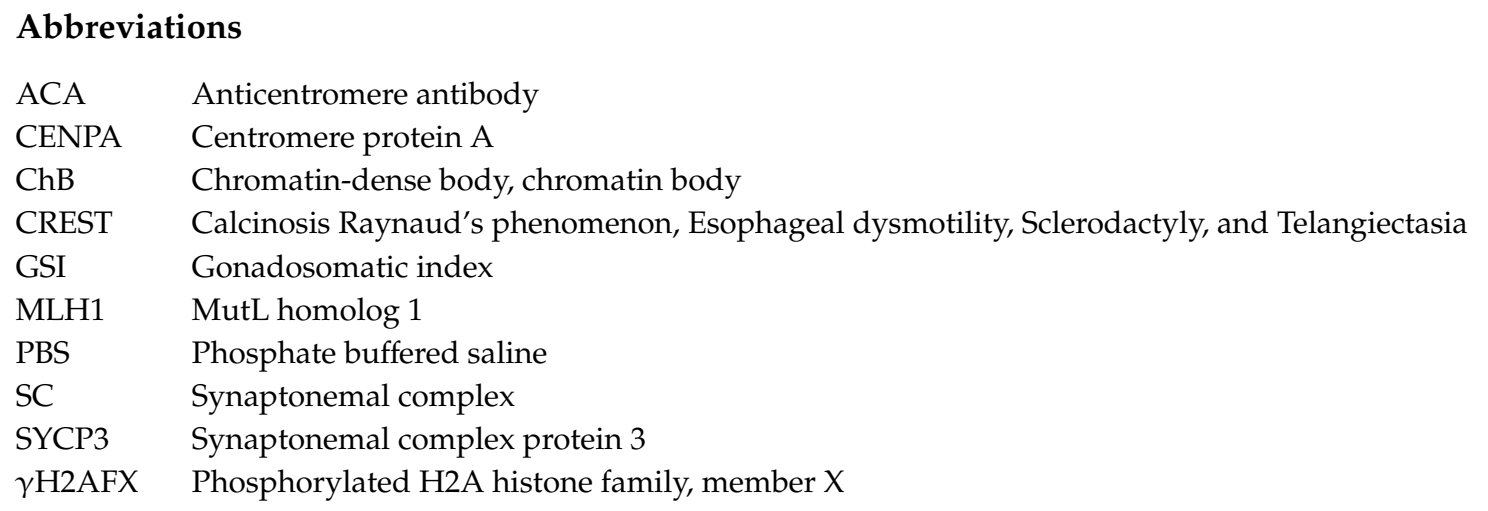

\section{References}

1. Dobzhansky, T. Genetics and the Origin of Species; Columbia University Press: New York, NY, USA, 1937; p. 364.

2. Benirschke, K. Sterility and fertility of interspecific mammalian hybrids. In Comparative Aspects of Reproductive Failure; Benirschke, K., Ed.; Springer: New York, NY, USA, 1967; pp. 218-234.

3. Basrur, P.K. Hybrid sterility. In Comparative Mammalian Cytogenetics; Benirschke, K., Ed.; Springer: New York, NY, USA, 1969; pp. 107-131.

4. White, M.J.D. Animal Cytology and Evolution; Cambridge University Press: London, UK; New York, NY, USA; Melbourne, Australia, 1977; p. 696.

5. Pavlova, S.V.; Searle, J.B. Chromosomes and speciation in mammals. In Mammalian Evolution, Diversity and Systematics; Zahos, F.E., Asher, A.J., Eds.; De Gruyter: Berlin, Germany; Boston, MA, UAS, 2018; pp. 17-38. [CrossRef]

6. Runemark, A.; Vallejo-Marin, M.; Meier, J.I. Eukaryote hybrid genomes. PLoS Genet. 2019, 15, e1008404. [CrossRef]

7. Johnson, N.A. Hybrid incompatibility genes: Remnants of a genomic battlefield? Trends Genet. 2010, 26, 317-325. [CrossRef]

8. Crespi, B.; Nosil, P. Conflictual speciation: Species formation via genomic conflict. Trend Ecol. Evol. 2013, 28, 48-57. [CrossRef] [PubMed]

9. McClintock, B. The significance of responses of the genome to challenge. Science 1984, 226, 792-801. [CrossRef]

10. Ha, M.; Lu, J.; Tian, L.; Ramachandran, V.; Kasschau, K.D.; Chapman, E.J.; Chen, X.; Wang, X.J.; Chen, Z.J. Small RNAs serve as a genetic buffer against genomic shock in Arabidopsis interspecific hybrids and allopolyploids. Proc. Natl. Acad. Sci. USA 2009, 106, 17835-17840. [CrossRef] [PubMed]

11. Petrov, D.A.; Schutzman, J.L.; Hartl, D.L.; Lozovskaya, E.R. Diverse transposable elements are mobilized in hybrid dysgenesis in Drosophila virilis. Proc. Natl. Acad. Sci. USA 1995, 92, 8050-8054. [CrossRef] [PubMed] 
12. Jones, R.N.; Langdon, T. The plant nucleus at war and peace: Genome organization in the interphase nucleus. In Plant Genome Diversity; Leitch, I.J., Greilhuber, J., Dolezel, J., Wendel, J.F., Eds.; Springer: Vienna, Austria, 2013; Volume 2, pp. 13-31.

13. Watkins, A.E. Hybrid sterility and incompatibility. J. Genet. 1932, 25, 125-162. [CrossRef]

14. Muller, H.J. Isolating mechanisms, evolution, and temperature. Biol. Symp. 1942, 6, 71-125.

15. Hale, D.W.; Washburn, L.; Eicher, E.M. Meiotic abnormalities in hybrid mice of the C57BL/6J $\times$ Mus spretus cross suggest a cytogenetic basis for Haldane's rule of hybrid sterility. Cytogenet. Genome Res. 1993, 63, 221-234. [CrossRef] [PubMed]

16. Forejt, J. Hybrid sterility in the mouse. Trends Genet. 1996, 12, 412-417. [CrossRef]

17. Ishishita, S.; Tsuboi, K.; Ohishi, N.; Tsuchiya, K.; Matsuda, Y. Abnormal pairing of X and Y sex chromosomes during meiosis I in interspecific hybrids of Phodopus campbelli and P. sungorus. Sci. Rep. 2015, 5, 9435. [CrossRef] [PubMed]

18. Haerty, W.; Singh, R.S. Gene regulation divergence is a major contributor to the evolution of Dobzhansky-Muller incompatibilities between species of Drosophila. Mol. Biol. Evol. 2006, 23, 1707-1714. [CrossRef] [PubMed]

19. Landry, C.R.; Hartl, D.L.; Ranz, J.M. Genome clashes in hybrids: Insights from gene expression. Heredity 2007, 99, 483-493. [CrossRef]

20. Brown, J.D.; O’Neill, R.J. Chromosomes, conflict, and epigenetics: Chromosomal speciation revisited. Annu. Rev. Genom. Hum. Genet. 2010, 11, 291-316. [CrossRef] [PubMed]

21. Johannisson, R.; Winking, H. Synaptonemal complexes of chains and rings in mice heterozygous for multiple Robertsonian translocations. Chromosome Res. 1994, 2, 137-145. [CrossRef] [PubMed]

22. Johannisson, R.; Winking, H. Pachytene chromosomes in trisomy 19 male mice with Robertsonian translocations. Chromosome Res. 1998, 6, 285-294. [CrossRef]

23. Sharma, T.; Bardhan, A.; Bahadur, M. Reduced meiotic fitness in hybrids with heterozygosity for heterochromatin in the speciating Mus terricolor complex. J. Biosci. 2003, 28, 189-198. [CrossRef]

24. Bhattacharyya, T.; Gregorova, S.; Mihola, O.; Anger, M.; Sebestova, J.; Denny, P.; Simecek, P.; Forejt, J. Mechanistic basis of infertility of mouse intersubspecific hybrids. Proc. Natl. Acad. Sci. USA 2013, 110, E468-E477. [CrossRef]

25. Forejt, J.; Čapková, J.; Gregorová, S. T (16:17) 43H translocation as a tool in analysis of the proximal part of chromosome 17 (including Tt gene complex) of the mouse. Genet. Res. 1980, 35, 165-177. [CrossRef]

26. Gill, A.E. Partial reproductive isolation of subspecies of the California vole, Microtus californicus. Genetica 1980, 52, 105-117. [CrossRef]

27. Tambovtseva, V.G.; Matveevsky, S.N.; Kashintsova, A.A.; Tretiakov, A.V.; Kolomiets, O.L.; Bakloushinskaya, I.Y. A meiotic mystery in experimental hybrids of the eastern mole vole (Ellobius tancrei, Mammalia, Rodentia). Vavilov J. Genet. Breed. 2019, 23, 239-243. [CrossRef]

28. Matsuda, Y.; Moens, P.B.; Chapman, V.M. Deficiency of X and Y chromosomal pairing at meiotic prophase in spermatocytes of sterile interspecific hybrids between laboratory mice (Mus domesticus) and Mus spretus. Chromosoma 1992, 101, 483-492. [CrossRef] [PubMed]

29. Matveevsky, S.N.; Malygin, V.M.; Lebedev, V.S.; Poplavskaya, N.S.; Surov, A.V.; Kolomiets, O.L. Sporadic disorders in the meiotic prophase I in Cricetulus barabensis hybrids (Cricetidae, Rodentia) do not lead to reproductive isolation between karyomorphs. Caryologia 2014, 67, 149-154. [CrossRef]

30. Gureeva, A.V.; Feoktistova, N.Y.; Matveevsky, S.N.; Kolomiets, O.L.; Surov, A.V. Speciation of Eversman and Mongolian hamsters (Allocricetulus, Cricetinae): Experimental hybridization. Biol. Bull. 2016, 43, 736-742. [CrossRef]

31. Ivanitskaya, E.; Rashkovetsky, L.; Nevo, E. Chromosomes in a hybrid zone of Israeli mole rats (Spalax, Rodentia). Russ. J. Genet. 2010, 46, 1149-1151. [CrossRef]

32. Matveevsky, S.N.; Pavlova, S.V.; Acaeva, M.M.; Kolomiets, O.L. Synaptonemal complex analysis of interracial hybrids between the Moscow and Neroosa chromosomal races of the common shrew Sorex araneus showing regular formation of a complex meiotic configuration (ring-of-four). Comp. Cytogenet. 2012, 6, 301-314. [CrossRef]

33. Lin, D.; Bi, K.; Conroy, C.J.; Lacey, E.A.; Schraiber, J.G.; Bowie, R.C. Mito-nuclear discordance across a recent contact zone for California voles. Ecol. Evol. 2018, 8, 6226-6241. [CrossRef] 
34. Chang, M.C.; Pickworth, S.; McGaughey, R.W. Experimental hybridization and chromosomes of hybrids. In Comparative Mammalian Cytogenetics; Benirschke, K., Ed.; Springer: New York, NY, USA, 1969; pp. 132-145.

35. King, M. Species Evolution: The Role of Chromosome Change; Cambridge University Press: New York, NY, USA, 1993; p. 336.

36. Lebedev, V.; Bogdanov, A.; Brandler, O.; Melnikova, M.; Enkhbat, U.; Tukhbatullin, A.; Abramov, A.; Surov, A.; Bakloushinskaya, I.; Bannikova, A. Cryptic variation in mole voles Ellobius (Arvicolinae, Rodentia) of Mongolia. Zool. Scripta 2020, 49, 535-548. [CrossRef]

37. Vorontsov, N.N.; Lyapunova, E.A.; Zakarjan, G.G.; Ivanov, V.G. The karyology and taxonomy of the genus Ellobius (Microtinae, Rodentia). In The Mammals: Evolution, Karyology, Faunistics, Systematics; Vorontsov, N.N., Ed.; Nauka: Novosibirsk, Russia, 1969; pp. 127-129. (In Russian)

38. Lyapunova, E.A.; Ivnitskii, S.B.; Korablev, V.P.; Yanina, I.Y. Complete Robertsonian fan of the chromosomal forms in the mole-vole superspecies Ellobius talpinus. Proc. USSR Acad. Sci. 1984, 274, 1209-1213. (In Russian)

39. Lyapunova, E.A.; Bakloushinskaya, I.Y.; Saidov, A.S.; Saidov, K.K. Dynamics of chromosome variation in mole voles Ellobius tancrei (Mammalia, Rodentia) in Pamiro-Alay in the period from 1982 to 2008. Russ. J. Genet. 2010, 46, 566-571. [CrossRef]

40. Bakloushinskaya, I.; Romanenko, S.A.; Serdukova, N.A.; Graphodatsky, A.S.; Lyapunova, E.A. A new form of the mole vole Ellobius tancrei Blasius, 1884 (Mammalia, Rodentia) with the lowest chromosome number. Comp. Cytogenet. 2013, 7, 163-169. [CrossRef] [PubMed]

41. Bakloushinskaya, I.; Lyapunova, E.A.; Saidov, A.S.; Romanenko, S.A.; O’Brien, P.C.; Serdyukova, N.A.; Ferguson-Smith, M.; Matveevsky, S.N.; Bogdanov, A. Rapid chromosomal evolution in enigmatic mammal with XX in both sexes, the Alay mole vole Ellobius alaicus Vorontsov et al., 1969 (Mammalia, Rodentia). Comp. Cytogenet. 2019, 13, 147-177. [CrossRef] [PubMed]

42. Romanenko, S.A.; Lyapunova, E.A.; Saidov, A.S.; O’Brien, P.; Serdyukova, N.A.; Ferguson-Smith, M.A.; Graphodatsky, A.S.; Bakloushinskaya, I. Chromosome translocations as a driver of diversification in Mole Voles Ellobius (Rodentia, Mammalia). Int. J. Mol. Sci. 2019, 20, 4466. [CrossRef]

43. Romanenko, S.A.; Sitnikova, N.A.; Serdukova, N.A.; Perelman, P.L.; Rubtsova, N.V.; Bakloushinskaya, I.Y.; Lyapunova, E.A.; Just, W.; Ferguson-Smith, M.A.; Yang, F.; et al. Chromosomal evolution of Arvicolinae (Cricetidae, Rodentia). II. The genome homology of two mole voles (genus Ellobius), the field vole and golden hamster revealed by comparative chromosome painting. Chromosome Res. 2007, 15, 891-897. [CrossRef] [PubMed]

44. Kolomiets, O.L.; Lyapunova, E.A.; Kalikinskaya, E.I.; Vorontsov, N.N.; Bogdanov, Y.F. Karyotyping of synaptonemal complexes of wild and hybrid forms of mole voles Ellobius, carrying Robertsonian rearrangements. In Proceedings of the Materials of the 5th All-Union Symposium "Molecular mechanisms of genetic processes", Moscow, Russia, 26-29 December 1983; Nauka Press: Moscow, Russia, 1983; p. 31. (In Russian).

45. Kolomiets, O.L.; Lyapunova, E.A.; Mazurova, T.F.; Yanina, I.Y.; Bogdanov, Y.F. Varying ways of formation of synaptonemal complex trivalent in heterozygote hybrids by Robertson's translocation. In Molecular Mechanisms of Genetic Processes. Molecular Genetics, Evolution and Molecular-Genetic Bases of Selection; Nauka Press: Moscow, Russia, 1985; pp. 72-84. (In Russian)

46. Kolomiets, O.L.; Lyapunova, E.A.; Mazurova, T.F.; Yanina, I.Y.; Bogdanov, Y.F. Participation of heterochromatin in formation of synaptonemal complex chains in animals heterozygous for multiple Robertsonian translocation. Russ. J. Genet. 1986, 22, 273-283. (In Russian)

47. Lyapunova, E.A.; Yakimenko, L.V. Genetics of Ellobius (Ellobius Rodentia). IV. Decrease in the fertility of hybrids between the forms of Ellobius talpinus subspecies with different chromosome numbers. Genetika 1985, 21, 1960-1968. (In Russian)

48. Lyapunova, E.A.; Baklushinskaya, I.Y.; Kolomiets, O.L.; Mazurova, T.F. Analysis of fertility of hybrids of multi-chromosomal forms in mole-voles of the super-species Ellobius tancrei differing in a single pair of Robertsonian metacentrics. Proc. USSR Acad. Sci. 1990, 310, 26-29. (In Russian)

49. Bakloushinskaya, I.Y.; Romanenko, S.A.; Graphodatsky, A.S.; Matveevsky, S.N.; Lyapunova, E.A.; Kolomiets, O.L. The role of chromosome rearrangements in the evolution of mole voles of the genus Ellobius (Rodentia, Mammalia). Russ. J. Genet. 2010, 46, 1143-1145. [CrossRef] 
50. Bakloushinskaya, I.Y.; Matveevsky, S.N.; Romanenko, S.A.; Serdukova, N.A.; Kolomiets, O.L.; Spangenberg, V.E.; Lyapunova, E.A.; Graphodatsky, A.S. A comparative analysis of the mole vole sibling species Ellobius tancrei and E. talpinus (Cricetidae, Rodentia) through chromosome painting and examination of synaptonemal complex structures in hybrids. Cytogenet. Genome Res. 2012, 136, 199-207. [CrossRef]

51. Matveevsky, S.; Bakloushinskaya, I.; Tambovtseva, V.; Romanenko, S.; Kolomiets, O. Analysis of meiotic chromosome structure and behavior in Robertsonian heterozygotes of Ellobius tancrei (Rodentia, Cricetidae): A case of monobrachial homology. Comp. Cytogenet. 2015, 9, 691. [CrossRef]

52. Matveevsky, S.; Kolomiets, O.; Bogdanov, A.; Hakhverdyan, M.; Bakloushinskaya, I. Chromosomal evolution in mole voles Ellobius (Cricetidae, Rodentia): Bizarre sex chromosomes, variable autosomes and meiosis. Genes 2017, 8, 306. [CrossRef] [PubMed]

53. Bogdanov, Y.F.; Kolomiets, O.L.; Lyapunova, E.A.; Yanina, I.Y.; Mazurova, T.F. Synaptonemal complexes and chromosome chains in the rodent Ellobius talpinus heterozygous for ten Robertsonian translocations. Chromosoma 1986, 94, 94-102. [CrossRef] [PubMed]

54. Adebayo, A.O.; Oke, B.O.; Akinloye, A.K. Characterizing the gonadosomatic index and its relationship with age in greater cane rat (Thryonomys swinderianus, Temminck). J. Vet. Anat. 2009, 2, 53-59. [CrossRef]

55. Pochron, S.T.; Wright, P.C.; Schaentzler, E.; Ippolito, M.; Rakotonirina, G.; Ratsimbazafy, R.; Rakotosoa, R. Effect of season and age on the gonadosomatic index of Milne-Edwards' sifakas (Propithecus diadema edwardsi) in Ranomafana National Park, Madagascar. Int. J. Primatol. 2002, 23, 355-364. [CrossRef]

56. Gomendio, M.; Martin-Coello, J.; Crespo, C.; Magaña, C.; Roldan, E.R. Sperm competition enhances functional capacity of mammalian spermatozoa. Proc. Natl. Acad. Sci. USA 2006, 103, 15113-15117. [CrossRef] [PubMed]

57. De Boer, P.D.; de Jong, J.H. Chromosome pairing and fertility in mice. In Fertility and Chromosome Pairing: Recent Studies in Plants and Animals; Gillies, C.B., Ed.; CRC Press, Inc.: Boca Raton, FL, USA, 1989; pp. 37-76.

58. Kolomiets, O.L.; Vorontsov, N.N.; Lyapunova, E.A.; Mazurova, T.F. Ultrastructure, meiotic behavior, and evolution of sex chromosomes of the genus Ellobius. Genetica 1991, 84, 179-189. [CrossRef]

59. Matveevsky, S.; Bakloushinskaya, I.; Kolomiets, O. Unique sex chromosome systems in Ellobius: How do male XX chromosomes recombine and undergo pachytene chromatin inactivation? Sci. Rep. 2016, 6, 29949. [CrossRef] [PubMed]

60. Matveevsky, S.N. Neocentromeres in the structure of the non-Robertsonian submetacentric chromosome pairs of Ellobius tancrei. In Proceedings of the Materials of the XVIII International Conference "Lomonosov-2011" for Students, Graduate Students and Young Scientists (Genetics Subsection), Moscow, Russia, 11-15 April 2011; Andreev, A.I., Andriyanov, A.V., Antipov, E.A., Chistyakova, M.V., Eds.; p. 94. (In Russian).

61. Matveevsky, S.N. Signs of Sexual Dimorphism in Meiosis and Karyotype Variability of Mole Vole Ellobius (Rodentia, Mammalia). Ph.D. Thesis, NI Vavilov Institute of General Genetics of Russian Academy of Science, Moscow, Russia, 2011. Supervisor Dr. O.L. Kolomiets. pp. 1-172. (In Russian).

62. Segura, J.; Ferretti, L.; Ramos-Onsins, S.; Capilla, L.; Farré, M.; Reis, F.; Oliver-Bonet, M.; Fernández-Bellón, H.; Garcia, F.; Garcia-Caldés, M.; et al. Evolution of recombination in eutherian mammals: Insights into mechanisms that affect recombination rates and crossover interference. Proc. Biol. Sci. 2013, 280, 20131945. [CrossRef]

63. Arnold, M.L. Natural Hybridization and Evolution; Oxford University Press: New York, NY, USA, 1993 ; p. 214.

64. Abbott, R.J.; Barton, N.H.; Good, J.M. Genomics of hybridization and its evolutionary consequences. Mol. Ecol. 2016, 25, 2325-2332. [CrossRef] [PubMed]

65. Moses, M.J.; Karatsis, P.A.; Hamilton, A.E. Synaptonemal complex analysis of heteromorphic trivalents in lemur hybrids. Chromosoma 1979, 70, 141-160. [CrossRef]

66. Ratomponirina, C.; Brun, B.; Rumpler, Y. Synaptonemal complexes in Robertsonian translocation heterozygous in lemurs. In Kew Chromosome Conference 3; Brandham, P.E., Ed.; HMSO: London, UK, 1988; pp. 65-73.

67. Wilson, D.E.; Reeder, D.M. Mammal Species of the World: A Taxonomic and Geographic Reference; JHU Press: Baltimore, MA, USA, 2005; Volume 1.

68. Schwitzer, C.; Mittermeier, R.A.; Louis, E.E., Jr.; Richardson, M. Family Lemuridae (Bamboo, True and Ruffed Lemurs). In Handbook of the Mammals of the World. Volume 3: Primates; Mittermeier, R.A., Wilson, D.E., Eds.; Lynx Edicions: Barcelona, Spain, 2013; pp. 90-141. 
69. Hauffe, H.C.; Searle, J.B. Chromosomal heterozygosity and fertility in house mice (Mus musculus domesticus) from Northern Italy. Genetics 1998, 150, 1143-1154.

70. Grao, P.; Coll, M.D.; Ponsa, M.; Egozcue, J. Trivalent behavior during prophase I in male mice heterozygous for three Robertsonian translocations: An electron-microscopic study. Cytogenet. Genome Res. 1989, 52, 105-110. [CrossRef]

71. Wallace, B.M.N.; Searle, J.B.; Everett, C.A. The effect of multiple simple Robertsonian heterozygosity on chromosome pairing and fertility of wild-stock house mice (Mus musculus domesticus). Cytogenet. Cell Genet. 2002, 96, 276-286. [CrossRef]

72. Manterola, M.; Page, J.; Vasco, C.; Berríos, S.; Parra, M.T.; Viera, A.; Rufas, J.S.; Zuccotti, M.; Garagna, S.; Fernández-Donoso, R. A high incidence of meiotic silencing of unsynapsed chromatin is not associated with substantial pachytene loss in heterozygous male mice carrying multiple simple Robertsonian translocations. PLoS Genet. 2009, 5, e1000625. [CrossRef]

73. Borodin, P.M.; Rogatcheva, M.B.; Zhelezova, A.I.; Oda, S.I. Chromosome pairing in inter-racial hybrids of the house musk shrew (Suncus murinus, Insectivora, Soricidae). Genome 1998, 41, 79-90. [CrossRef]

74. Rogatcheva, M.B.; Aulchenko, Y.S.; Oda, S.I.; Zhelezova, A.I.; Serova, I.A.; Axenovich, T.I.; Borodin, P.M. Chromosomal and genic mechanisms of reproductive isolation: The case of Suncus murinus. Acta Theriol. 2000, 45, 147-160. [CrossRef]

75. Rieseberg, L.H. Chromosomal rearrangements and speciation. Trends Ecol. Evol. 2001, 16, 351-358. [CrossRef]

76. Livingstone, K.; Rieseberg, L. Chromosomal evolution and speciation: A recombination-based approach. New Phytol. 2004, 161, 107-112. [CrossRef]

77. Cattanach, B.M.; Moseley, H. Nondisjunction and reduced fertility caused by the tobacco mouse metacentric chromosomes. Cytogenet. Genome Res. 1973, 12, 264-287. [CrossRef]

78. Davisson, M.T.; Akeson, E.C. Recombination suppression by heterozygous Robertsonian chromosomes in the mouse. Genetics 1993, 133, 649-667.

79. Baker, S.M.; Plug, A.W.; Prolla, T.A.; Bronner, C.E.; Harris, A.C.; Yao, X.; Christie, D.M.; Monell, C.; Arnheim, N.; Bradley, N.; et al. Involvement of mouse Mlh1 in DNA mismatch repair and meiotic crossing over. Nat. Genet. 1996, 13, 336-342. [CrossRef]

80. Eaker, S.; Pyle, A.; Cobb, J.; Handel, M.A. Evidence for meiotic spindle checkpoint from analysis of spermatocytes from Robertsonian-chromosome heterozygous mice. J. Cell Sci. 2001, 114, 2953-2965. [PubMed]

81. Eaker, S.; Cobb, J.; Pyle, A.; Handel, M.A. Meiotic prophase abnormalities and metaphase cell death in MLH1-deficient mouse spermatocytes: Insights into regulation of spermatogenic progress. Dev. Biol. 2002, 249, 85-95. [CrossRef] [PubMed]

82. Morelli, M.A.; Cohen, P.E. Not all germ cells are created equal: Aspects of sexual dimorphism in mammalian meiosis. Reproduction 2005, 130, 761-781. [CrossRef]

83. Cheeseman, I.M. The kinetochore. Cold Spring Harb. Perspect. Biol. 2014, 6, a015826. [CrossRef] [PubMed]

84. Talbert, P.B.; Henikoff, S. What makes a centromere? Exp. Cell Res. 2020, 389, 111895. [CrossRef]

85. Henikoff, S.; Ahmad, K.; Malik, H.S. The centromere paradox: Stable inheritance with rapidly evolving DNA. Science 2001, 293, 1098-1102. [CrossRef]

86. Garagna, S.; Zuccotti, M.; Capanna, E.; Redi, C.A. High-resolution organization of mouse telomeric and pericentromeric DNA. Cytogenet. Genome Res. 2002, 96, 125-129. [CrossRef] [PubMed]

87. Plohl, M.; Luchetti, A.; Meštrović, N.; Mantovani, B. Satellite DNAs between selfishness and functionality: Structure, genomics and evolution of tandem repeats in centromeric (hetero) chromatin. Gene 2008, 409, 72-82. [CrossRef]

88. Ferreri, G.C.; Brown, J.D.; Obergfell, C.; Jue, N.; Finn, C.E.; O’Neill, M.J.; O’Neill, R.J. Recent amplification of the kangaroo endogenous retrovirus, KERV, limited to the centromere. J. Virol. 2011, 85, 4761-4771. [CrossRef]

89. Chang, C.H.; Chavan, A.; Palladino, J.; Wei, X.; Martins, N.M.; Santinello, B. Islands of retroelements are major components of Drosophila centromeres. PLoS Biol. 2019, 17, e3000241. [CrossRef] [PubMed]

90. Amor, D.J.; Choo, K.A. Neocentromeres: Role in human disease, evolution, and centromere study. Am. J. Hum. Genet. 2002, 71, 695-714. [CrossRef]

91. Dalal, Y. Epigenetic specification of centromeres. Biochem. Cell Biol. 2009, 87, 273-282. [CrossRef] 
92. Bernad, R.; Sánchez, P.; Losada, A. Epigenetic specification of centromeres by CENP-A. Exp. Cell Res. 2009, 315, 3233-3241. [CrossRef] [PubMed]

93. Musacchio, A.; Desai, A. A molecular view of kinetochore assembly and function. Biology 2017, 6, 5. [CrossRef] [PubMed]

94. Berríos, S.; Manieu, C.; López-Fenner, J.; Ayarza, E.; Page, J.; González, M.; Manterola, M.; Fernández-Donoso, R. Robertsonian chromosomes and the nuclear architecture of mouse meiotic prophase spermatocytes. Biol. Res. 2014, 47, 16. [CrossRef] [PubMed]

95. Richards, E.J.; Elgin, S.C. Epigenetic codes for heterochromatin formation and silencing: Rounding up the usual suspects. Cell 2002, 108, 489-500. [CrossRef]

96. Nishibuchi, G.; Déjardin, J. The molecular basis of the organization of repetitive DNA-containing constitutive heterochromatin in mammals. Chromosome Res. 2017, 25, 77-87. [CrossRef]

97. Ribeiro, S.A.; Vagnarelli, P.; Dong, Y.; Hori, T.; McEwen, B.F.; Fukagawa, T.; Flors, C.; Earnshaw, W.C. A super-resolution map of the vertebrate kinetochore. Proc. Natl. Acad. Sci. USA 2010, 107, 10484-10489. [CrossRef]

98. Gil-Fernández, A.; Saunders, P.; Martín-Ruiz, M.; Ribagorda, M.; López-Jiménez, P.; Jeffries, D.L.; Parra, M.T.; Viera, A.; Rufas, J.S.; Perrin, N.; et al. Meiosis reveals the early steps in the evolution of a neo-XY sex chromosome pair in the African pygmy mouse Mus minutoides. bioRxiv 2020, 177329. [CrossRef]

99. Mestrović, N.; Plohl, M.; Mravinac, B.; Ugarković, D. Evolution of satellite DNAs from the genus Palorus-experimental evidence for the" library" hypothesis. Mol. Biol. Evol. 1998, 15, 1062-1068. [CrossRef]

100. Lee, H.R.; Zhang, W.; Langdon, T.; Jin, W.; Yan, H.; Cheng, Z.; Jiang, J. Chromatin immunoprecipitation cloning reveals rapid evolutionary patterns of centromeric DNA in Oryza species. Proc. Natl. Acad. Sci. USA 2005, 102, 11793-11798. [CrossRef]

101. Talbert, P.B.; Kasinathan, S.; Henikoff, S. Simple and complex centromeric satellites in Drosophila sibling species. Genetics 2018, 208, 977-990. [CrossRef]

102. Salser, W.; Bowen, S.; Browne, D.; El-Adli, F.; Fedoroff, N.; Fry, K. Investigation of the organization of mammalian chromosomes at the DNA sequence level. Fed. Proc. 1976, 35, 23-35.

103. Miklos, G.L.G. Localized highly repetitive DNA sequences in vertebrate and invertebrate genomes. In Molecular Evolutionary Genetics; MacIntyre, R.J., Ed.; Plenum Press: New York, NY, USA, 1985; pp. 241-321.

104. Smalec, B.M.; Heider, T.N.; Flynn, B.L.; O'Neill, R.J. A centromere satellite concomitant with extensive karyotypic diversity across the Peromyscus genus defies predictions of molecular drive. Chromosome Res. 2019, 27, 237-252. [CrossRef]

105. O'Neill, R.J.W.; O'Neill, M.J.; Graves, J.A.M. Undermethylation associated with retroelement activation and chromosome remodelling in an interspecific mammalian hybrid. Nature 1998, 393, 68-72. [CrossRef]

106. Metcalfe, C.J.; Bulazel, K.V.; Ferreri, G.C.; Schroeder-Reiter, E.; Wanner, G.; Rens, W.; Obergfell, C.; Eldridge, M.D.B.; O'Neill, R.J. Genomic instability within centromeres of interspecific marsupial hybrids. Genetics 2007, 177, 2507-2517. [CrossRef]

107. Brown, J.D.; Mitchell, S.E.; O'Neill, R.J. Making a long story short: Noncoding RNAs and chromosome change. Heredity 2012, 108, 42-49. [CrossRef]

108. Lyapunova, E.A.; Vorontsov, N.N. Genetics of Ellobius (Rodentia). I. Karyological characteristics of four Ellobius species. Russ. J. Genet. 1978, 14, 2012-2024. (In Russian)

109. Matveevsky, S.; Kolomiets, O.; Bogdanov, A.; Alpeeva, E.; Bakloushinskaya, I. Meiotic chromosome contacts as a plausible prelude for Robertsonian translocations. Genes 2020, 11, 386. [CrossRef]

110. Cremer, T.; Kurz, A.; Zirbel, R.; Dietzel, S.; Rinke, B.; Schröck, E.; Speicher, M.R.; Mathieu, U.; Jauch, A.; Emmerich, P.; et al. Role of chromosome territories in the functional compartmentalization of the cell nucleus. Cold Spring Harb. Symp. Quant. Biol. 1993, 58, 777-792. [CrossRef]

111. Parada, L.A.; Misteli, T. Chromosome positioning in the interphase nucleus. Trend Cell Biol. 2002, 12, 425-432. [CrossRef]

112. Foster, H.A.; Abeydeera, L.R.; Griffin, D.K.; Bridger, J.M. Non-random chromosome positioning in mammalian sperm nuclei, with migration of the sex chromosomes during late spermatogenesis. J. Cell Sci. 2005, 118, 1811-1820. [CrossRef]

113. Cremer, T.; Cremer, M. Chromosome territories. Cold Spring Harb. Perspect. Biol. 2010, 2, a003889. [CrossRef]

114. Cremer, T.; Cremer, M.; Dietzel, S.; Müller, S.; Solovei, I.; Fakan, S. Chromosome territories-a functional nuclear landscape. Curr. Opin. Cell Biol. 2006, 18, 307-316. [CrossRef] 
115. Cremer, T.; Cremer, C. Chromosome territories, nuclear architecture and gene regulation in mammalian cells. Nat. Rev. Genet. 2001, 2, 292-301. [CrossRef]

116. Misteli, T. Chromosome territories: The arrangement of chromosomes in the nucleus. Nat. Educ. 2008, 1, 167.

117. Tanabe, H.; Habermann, F.A.; Solovei, I.; Cremer, M.; Cremer, T. Non-random radial arrangements of interphase chromosome territories: Evolutionary considerations and functional implications. Mutat. Res. 2002, 504, 37-45. [CrossRef]

118. Mora, L.; Ponsà, M.; Garcia, M. Chromosomal territories in evolutionary rearranged primate Chromosomes. In Primate Cytogenetics and Comparative Genomics; Sineo, L., Stanyon, R., Eds.; Firenze University Press: Firenze, Italy, 2006; pp. 77-85.

119. Politz, J.C.R.; Scalzo, D.; Groudine, M. The redundancy of the mammalian heterochromatic compartment. Curr. Opin. Genet. Dev. 2016, 37, 1-8. [CrossRef]

120. Garagna, S.; Zuccotti, M.; Thornhill, A.; Fernandez-Donoso, R.; Berrios, S.; Capanna, E.; Redi, C.A. Alteration of nuclear architecture in male germ cells of chromosomally derived subfertile mice. J. Cell Sci. 2001, 114, 4429-4434.

121. Oberdoerffer, P.; Sinclair, D.A. The role of nuclear architecture in genomic instability and ageing. Nat. Rev. Mol. Cell Biol. 2007, 8, 692-702. [CrossRef] [PubMed]

122. Lammerding, J. Mechanics of the nucleus. Compr. Physiol. 2011, 1, 783-807. [CrossRef]

123. Fournier, A.; McLeer-Florin, A.; Lefebvre, C.; Duley, S.; Barki, L.; Ribeyron, J.; Alboukadel, K.; Hamaidia, S.; Granjon, A.; Gressin, R.; et al. 1q12 chromosome translocations form aberrant heterochromatic foci associated with changes in nuclear architecture and gene expression in B cell lymphoma. EMBO Mol. Med. 2010, 2, 159-171. [CrossRef]

124. Berríos, S.; Fernández-Donoso, R.; Page, J.; Ayarza, E.; Capanna, E.; Solano, E.; Castiglia, R. Hexavalents in spermatocytes of Robertsonian heterozygotes between Mus $m$. domesticus $2 \mathrm{n}=26$ from the Vulcano and Lipari Islands (Aeolian Archipelago, Italy). Eur. J. Histochem. 2018, 62. [CrossRef]

125. Abdelhedi, F.; Chalas, C.; Petit, J.M.; Abid, N.; Mokadem, E.; Hizem, S.; Kamoun, H.; Keskes, L.; Dupont, J. Altered three-dimensional organization of sperm genome in DPY19L2-deficient globozoospermic patients. J. Assist. Reprod. Genet. 2019, 36, 69-77. [CrossRef]

126. Rosin, L.F.; Crocker, O.; Isenhart, R.L.; Nguyen, S.C.; Xu, Z.; Joyce, E.F. Chromosome territory formation attenuates the translocation potential of cells. eLife 2019, 8, e49553. [CrossRef]

127. Alsheimer, M.; von Glasenapp, E.; Hock, R.; Benavente, R. Architecture of the nuclear periphery of rat pachytene spermatocytes: Distribution of nuclear envelope proteins in relation to synaptonemal complex attachment sites. Mol. Biol. Cell 1999, 10, 1235-1245. [CrossRef]

128. Hernández-Hernández, A.; Vázquez-Nin, G.H.; Echeverría, O.M.; Recillas-Targa, F. Chromatin structure contribution to the synaptonemal complex formation. Cell. Mol. Life Sci. 2009, 66, 1198-1208. [CrossRef]

129. Alsheimer, M. The dance floor of meiosis: Evolutionary conservation of nuclear envelope attachment and dynamics of meiotic telomeres. In Meiosis. Genome Dynamics; Benavente, R., Wolf, J.N., Eds.; Karger Publishers: Basel, Switzerland, 2009; pp. 81-93. [CrossRef]

130. Schimenti, J. Synapsis or silence. Nat. Genet. 2005, 37, 11-13. [CrossRef]

131. Turner, J.M.; Mahadevaiah, S.K.; Fernandez-Capetillo, O.; Nussenzweig, A.; Xu, X.; Deng, C.X.; Burgoyne, P.S. Silencing of unsynapsed meiotic chromosomes in the mouse. Nat. Genet. 2005, 37, 41-47. [CrossRef]

132. Berrios, S.; Ayarza, E.; Moreno, M.; Paulos, A.; Fernández-Donoso, R. Non-random distribution of the pericentromeric heterochromatin in meiotic prophase nuclei of mammalian spermatocytes. Genetica 1999, 106, 187-195. [CrossRef]

133. Berríos, S.; Fernández-Donoso, R.; Pincheira, J.; Page, J.; Manterola, M.; Cerda, M.C. Number and nuclear localisation of nucleoli in mammalian spermatocytes. Genetica 2004, 121, 219-228. [CrossRef]

134. Berríos, S. Nuclear architecture of mouse spermatocytes: Chromosome topology, heterochromatin, and nucleolus. Cytogenet. Genome Res. 2017, 151, 61-71. [CrossRef] [PubMed]

135. Ribagorda, M.; Berríos, S.; Solano, E.; Ayarza, E.; Martín-Ruiz, M.; Gil-Fernández, A.; Parra, M.T.; Viera, A.; Rufas, J.S.; Capanna, E.; et al. Meiotic behavior of a complex hexavalent in heterozygous mice for Robertsonian translocations: Insights for synapsis dynamics. Chromosoma 2019, 128, 149-163. [CrossRef]

136. Matveevsky, S.N.; Kolomiets, O.L. Types of synaptonemal complex chains in heterozygotes for multiple Robertsonian translocations. Factors Exp. Evol. Org. 2011, 10, 42-47. (In Russian) 
137. Matveevsky, S.N.; Kolomiets, O.L. Synaptonemal complex configurations in Robertsonian heterozygotes. Tsitologia 2016, 58, 309-314.

138. Turner, J.M. Meiotic sex chromosome inactivation. Development 2007, 134, 1823-1831. [CrossRef]

139. Burgoyne, P.S.; Mahadevaiah, S.K.; Turner, J.M. The consequences of asynapsis for mammalian meiosis. Nat. Rev. Genet. 2009, 10, 207-216. [CrossRef]

140. Homolka, D.; Ivanek, R.; Capkova, J.; Jansa, P.; Forejt, J. Chromosomal rearrangement interferes with meiotic X chromosome inactivation. Genome Res. 2007, 17, 1431-1437. [CrossRef]

141. Berríos, S.; Manterola, M.; Prieto, Z.; López-Fenner, J.; Page, J.; Fernández-Donoso, R. Model of chromosome associations in Mus domesticus spermatocytes. Biol. Res. 2010, 43, 275-285. [CrossRef]

142. Kolomiets, O.; Matveevsky, S.; Bakloushinskaya, I. Sexual dimorphism in prophase I of meiosis in the Northern mole vole (Ellobius talpinus Pallas, 1770) with isomorphic (XX) chromosomes in males and females. Comp. Cytogenet. 2010, 455. [CrossRef]

143. Page, J.; Suja, J.A.; Santos, J.L.; Rufas, J.S. Squash procedure for protein immunolocalization in meiotic cells. Chromosome Res. 1998, 6, 639-642. [CrossRef]

144. De Boer, P. Chromosomal causes for fertility reduction in mammals. In Chemical Mutagens; De Serres, F.G., Ed.; Springer: Boston, MA, USA, 1986; pp. 427-467.

145. Miklos, G.L.G. Sex-chromosome pairing and male fertility. Cytogenet. Cell Genet. 1974, 13, 558-577. [CrossRef]

146. Zhao, H.; Zhu, X.; Wang, K.; Gent, J.I.; Zhang, W.; Dawe, R.K.; Jiang, J. Gene expression and chromatin modifications associated with maize centromeres. G3 Genes Genomes Genet. 2016, 6, 183-192. [CrossRef]

Publisher's Note: MDPI stays neutral with regard to jurisdictional claims in published maps and institutional affiliations.

(C) 2020 by the authors. Licensee MDPI, Basel, Switzerland. This article is an open access article distributed under the terms and conditions of the Creative Commons Attribution (CC BY) license (http://creativecommons.org/licenses/by/4.0/). 